NATHANIEL PERSILY

\title{
FIG LEAVES AND TEA LEAVES IN THE SUPREME COURT'S RECENT ELECTION LAW DECISIONS
}

In the field of American election law, political developments and the Supreme Court's docket often progress along parallel tracks. Those tracks rarely intersect with such salience and notoriety as in the 2000 election controversy. More often, the issues the Supreme Court decides have immediate thematic relevance to the ongoing campaign, even when the Court is not actually deciding a case that grows out of the campaign itself. Such was the case with the Supreme Court's election law docket from the 2007-2008 term and the historic 2008 election. The five election law cases the Court decided hinted at ongoing controversies with incarnations in the 2008 campaign.

The election law docket was diverse, including a case on each of the topics that have preoccupied election lawyers and academics in recent years: campaign finance, ${ }^{1}$ voter identification, ${ }^{2}$ the Voting

Nathaniel Persily is Charles Keller Beekman Professor of Law and Political Science, Columbia Law School.

Author's note: Thanks to Jason M. Levy for excellent research assistance, and to Richard Briffault, Guy-Uriel Charles, Christopher Elmendorf, Ned Foley, Heather Gerken, Richard Hasen, Samuel Issacharoff, Pamela Karlan, Richard Pildes, and David Strauss for helpful comments.

${ }^{1}$ Davis v FEC, 128 S Ct 2759 (2008).

${ }^{2}$ Crawford v Marion County Election Bd, 128 S Ct 1610 (2008).

(c) 2009 by The University of Chicago. All rights reserved.

978-0-226-36253-3/2009/2008-0003\$10.00 
Rights Act (VRA), ${ }^{3}$ and the regulation of political parties. ${ }^{4}$ As the Supreme Court considered the constitutionality of a federal law that attempted to mitigate the funding advantages of rich candidates, both John McCain and Barack Obama grappled with legal and political controversies growing out of the acceptance or nonacceptance of public funding designed for that purpose. ${ }^{5}$ While the Court attempted to define the constitutional bounds of a political party's power in the nomination process, Democrats in Florida and Michigan were suing their party to force it to seat delegations elected in contravention of party rules. ${ }^{6}$ As the parties geared up for the many fights in the fall over voter fraud and voter suppression, the Supreme Court weighed in with its first full opinion concerning voter identification requirements. ${ }^{7}$ Finally, as Barack Obama made history as the first successful African American presidential candidate, the Court considered whether to give an expansive or restricted reading to provisions of the Voting Rights Act that, in indirect and direct ways, made that historic event possible. ${ }^{8}$

At the highest levels of abstraction, the themes in these two parallel universes appear well connected, but the cases from the 2007-2008 term, with perhaps one exception, had very little salience with the public. The one exception might be the Court's decision in Crawford $v$ Marion County ${ }^{9}$ upholding Indiana's law requiring voters to present a photo ID. That case represented the latest chapter in the sordid story of perceived fraud and disenfranchisement (or "integrity" versus "access") that had played out in several states

\footnotetext{
${ }^{3}$ Riley v Kennedy, 128 S Ct 1970 (2008).

${ }^{4}$ Wash. State Grange v Wash. State Republican Party, 128 S Ct 1184 (2008); New York v Lopez Torres, 128 S Ct 791 (2008).

${ }^{5}$ See, for example, Michael Cooper, McCain to Obama: "Keep Your Word," NY Times Polit Blog (Apr 11, 2008), online at http://thecaucus.blogs.nytimes.com/2008/04/11/ mccain-to-obama-keep-your-word.

${ }^{6}$ See, for example, Katherine Q. Seelye, Florida and Michigan May See Delegates Halved, NY Times (May 29, 2008), online at http://www.nytimes.com/2008/05/29/us/politics/29 dems.html? partner = permalink\&exprod = permalink; Katherine Q. Seelye, Clinton Camp's Argument: No Michigan Delegates for You, NY Times Polit Blog (May 30, 2008), online at http:// thecaucus.blogs.nytimes.com/2008/05/30/clinton-camps-argument-no-michigan-delegatesfor-you/; Order Granting Motion for Summary Judgment; Motion to Dismiss, Nelson v Dean, No 4:07cv427-RH (entered Dec 14, 2007), online at http://moritzlaw.osu.edu/electionlaw/ litigation/documents/Nelson-ORDER12-14-07.pdf.

${ }^{7}$ See Crawford, 128 S Ct 1610 (2008).

${ }^{8}$ See Riley, 128 S Ct 1970.

${ }^{9} 128$ S Ct 1610.
} 
that passed ID requirements. ${ }^{10}$ The Court also considered the case in the midst of the high-profile controversy surrounding the firing of U.S. attorneys unwilling to prosecute voter fraud claims. ${ }^{11}$ However, even for Crawford, the available data suggest the stakes were much lower than either side had claimed. ${ }^{12}$

The other four cases the Court decided barely attracted attention beyond the election law bar. In Davis v FEC, ${ }^{13}$ the only five-to-four decision of the bunch, the Court struck down the so-called Millionaire's Amendment provision of the Bipartisan Campaign Reform Act (BCRA). ${ }^{14}$ The Court found the law violated the First Amendment rights of some self-financed candidates by allowing their opponents to take advantage of the law's provision that allowed them to raise contributions triple the normal limits. ${ }^{15}$ The provision was sufficiently underutilized and below the radar that it drew little criticism despite the deeply divided Court. ${ }^{16}$ Similarly, the Court's seven-to-two decision in Riley $v$ Kennedy ${ }^{17}$ interpreting Section 5 of the Voting Rights Act involved an issue that was difficult to understand and rarely important. ${ }^{18}$ The Court held that a preexisting

${ }^{10}$ See Purcell $v$ Gonzalez, 127 S Ct 5 (2006) (sustaining at a preliminary stage a district court decision upholding a voter ID law); Common Cause/Georgia v Billups, No 07-14664 (11th Cir 2009), online at http://www.ca11.uscourts.gov/opinions/ops/200714664.pdf(rejecting challenge to Georgia photo ID law). Weinschenk $v$ State, 203 SW3d 201 (Mo 2006) (striking down Missouri voter ID law).

${ }^{11}$ See Siobhan Morrissey, Newsmaker of the Year, 94 ABA J 26 (2008) (naming Alberto Gonzales "Newsmaker of the Year," largely for his role in the firing of eight U.S. attorneys); Philip Chignon, Democrats Were Targets in Inquiries, Panel Is Told, NY Times (Oct 24, 2007), online at http://www.nytimes.com/2007/10/24/Washington/24prosecute.html?scp $=2 \& s q=$ gonzales + U.S.+ attorney\&st $=$ nyt (discussing U.S. attorney firing scandal).

${ }^{12}$ See Stephen Ansolabehere, Access versus Integrity in Voter Identification Requirements, 63 NYU Annual Surv Am L 613, 626 (2008) (demonstrating that the claims of both vote fraud and vote suppression were overblown); Michael J. Pitts, Empirically Assessing the Impact of Photo Identification at the Polls Through an Examination of Provisional Ballots, $24 \mathrm{~J}$ L \& Pol (forthcoming 2009) (estimating 400 voters in Indiana cast provisional ballots that went uncounted because of an ID problem).

${ }^{13} 128$ S Ct 2759 (2008).

${ }^{14} \mathrm{Id}$ at 2766.

${ }^{15}$ Id.

${ }^{16}$ But see Editorial, Millionaires Win, Wash Post B06 (June 29, 2008); Editorial, fustices for Free Speech, Wall St J (June 28, 2008), online at http://online.wsj.com/article/ SB121460646723712065.html?mod = googlenews_wsj\#printMode; Editorial, Millionaire's Amendment, NY Times (Apr 21, 2008), online at http://www.nytimes.com/2008/04/21/ opinion $/ 21 \mathrm{mon} 1 . h \mathrm{tml}$ ? scp $=2 \& \mathrm{sq}=$ Millionaire $\% 92 \mathrm{~s} \% 20$ Amendment $\% 20 \& \mathrm{st}=$ cse $($ dis cussing the case prior to oral argument).

${ }^{17} 128$ S Ct 1970 (2008).

${ }^{18} \mathrm{Id}$. 
state election law need not be precleared for compliance with the VRA once the succeeding state law was ruled unconstitutional by a state court. ${ }^{19}$ A similar result held in the Court's unanimous decision in New York $v$ Lopez Torres ${ }^{20}$ in which the Court upheld New York's unique method of nominating judicial candidates for the party's line on a general election ballot. Opponents had argued that the law gave too much power to party bosses, who could often structure nominating conventions to ensure that their favorites were guaranteed to win. ${ }^{21}$ Finally, in Washington State Grange v Washington State Republican Party, ${ }^{22}$ the Court (seven to two) upheld against a First Amendment challenge Washington's nonpartisan blanket primary, in which candidates can express a party preference on the ballot even against the wishes of the party itself.

This article reads the fig leaves (how the Court has papered over disagreement to craft apparent consensus) and the tea leaves (what the recent decisions portend for the future) from the Roberts Court's recent election law decisions. The greater consensus in these cases (four of five were decided by supermajorities), even given their lower salience, deserves an explanation. Chief Justice Roberts was the only Justice who joined the controlling opinions in each of the five cases the Court considered during that term. Indeed, he has joined the controlling opinion in all but one election law case his Court has considered. ${ }^{23}$ Compared to the Rehnquist Court, for example, the Roberts Court's initial signals are more directly attributable to the Chief Justice's efforts. Part I of this article discusses two such efforts from the 2007-2008 term. In some cases the Court achieved greater consensus by relying on the distinction between as-applied and facial challenges, a distinction that has undergone subtle transformations in the last few years. In others, the Court avoided disagreement by eschewing one of the concerns that had been percolating in prior cases-namely, the fear that election laws might be used as a tool for incumbent or partisan entrenchment. Part II looks at each of these cases as guides for what may lie ahead.

\footnotetext{
${ }^{19} \mathrm{Id}$ at 1982.

${ }^{20} 128$ S Ct 791 (2008).

${ }^{21} \mathrm{Id}$ at 799.

${ }^{22} 128$ S Ct 1184 (2008).

${ }^{23}$ Even in that one case, the Texas gerrymandering case LULAC $v$ Perry, he was in the minority on only one aspect of the case: the decision to strike down one district as violating Section 2 of the Voting Rights Act.
} 
In general, these cases suggest the Roberts Court will be quite restrained in its treatment of election laws, with the notable exception of its aggressive review of campaign finance reforms. It may have backed away somewhat from strong arguments concerning political party autonomy that found favor with the Rehnquist Court, while also giving states greater leeway when it comes to regulating voter and candidate access to the ballot. On issues of racial discrimination and the Voting Rights Act, the Roberts Court (which is really the Kennedy Court, in this regard) has yet to provide any clear signals. Part III presents some tentative conclusions.

\section{The Fig Leaves That Cloaked the 2007-2008 Term's Election Law Cases}

In the post-Bush $v$ Gore ${ }^{24}$ world, it had become traditional to view election law as one more arena in which the Court was closely divided along ideological lines. ${ }^{25}$ Whether the issue was partisan gerrymandering, ${ }^{26}$ campaign finance,${ }^{27}$ judicial elections,${ }^{28}$ the Voting Rights Act, ${ }^{29}$ or race and redistricting, ${ }^{30}$ the Rehnquist Court seemed evenly divided, with either Justice O'Connor or Justice Kennedy casting the decisive vote. ${ }^{31}$ In his confirmation hearings, John Roberts hoped things would be different, ${ }^{32}$ and the 2007-2008 term

${ }^{24} 531$ US 98 (2000).

${ }^{25}$ See Heather K. Gerken, Rashomon and the Roberts Court, 68 Ohio St L J 1213, 1213 (2007) (noting the highly fractured decisions in recent election law cases).

${ }^{26}$ See Vieth v fubelirer, 541 US 267 (2004); League of United Latin Am. Citizens v Perry, 548 US 399 (2006) (“LULAC").

${ }^{27}$ See McConnell v FEC, 540 US 93 (2003); FEC v Wis. Right to Life, Inc., 127 S Ct 2652 (2007) (“WRTL”); Colo. Republican Fed. Campaign Comm. v FEC, 533 US 431 (2001) ("Colorado Republican II").

${ }^{28}$ See Republican Party of Minnesota v White, 536 US 765 (2002).

${ }^{29}$ See Georgia v Ashcroft, 539 US 461 (2003); LULAC, 548 US 399.

${ }^{30}$ See Easley v Cromartie, 532 US 234 (2001).

${ }^{31}$ There are just a few exceptions to this general pattern of post-Bush $v$ Gore election law split decisions. In Randall v Sorrell, 548 US 230 (2006), the Court by a vote of six to three struck down Vermont's low contribution limits. In Clingman v Beaver, 544 US 581 (2005), the Court, in a fractured decision, upheld a law that prevented the Libertarian Party from allowing other parties' members to vote in its primary. Also, the first opinion in WRTL, 546 US 410, 412 (2006), was unanimous, but it merely remanded to the district court to entertain an as-applied challenge.

${ }^{32}$ See Editorial, The Roberts Court Returns, NY Times (Sept 30, 2007), online at http:// www.nytimes.com/2007/09/30/opinion/30sun1.html ("At his confirmation hearings, Chief Justice John Roberts told the Senate he had 'no agenda,' and famously compared his role to that of an umpire calling balls and strikes. He has also said he wants more consensus on the court, and fewer 5-to-4 decisions."). 
showed some promise in that regard..$^{33}$

As previously suggested, the greater consensus in the past term's election law cases derived, in part, from the low stakes-in both partisan and jurisprudential respects-these cases presented. With the exception of Crawford, in which the Justices nevertheless split six to three, none of these cases presented an issue the resolution of which would likely favor one party over another or even apply systematically to American elections. These cases were quite different, for example, than ones the Court had recently entertained concerning partisan gerrymandering or core issues of campaign finance. Therefore, the apparent consensus may prove to be a quirky result from an unusual docket limited to last term.

An alternative explanation, though, is that the approach the Court took in several of these cases suggests a move toward a style and type of argument that can gain a broader coalition than may have otherwise existed in such cases. ${ }^{34}$ In particular, the heavy reliance on the distinction between as-applied and facial challenges led the Court to decide these cases by larger majorities. Although the decisions are minimalist in appearance and ambiguous in actual meaning, this strategy has the virtue of projecting a spirit of judicial restraint and moderation. It therefore appeals to those on the fence who view siding with the majority as a small and perhaps reversible step, rather than the creation of a sweeping rule of law.

In addition, although the Court had ample opportunity with this docket to hint, as many academics had hoped,${ }^{35}$ in the direction of an election law jurisprudence founded on promoting competition, the Court's opinions were instead quite traditional in their approach. They balanced state interests against rights to vote, to associate, or to speak rather than asking whether the laws at issue represented moves entrenching incumbents or their parties. Several Justices who had voiced such concerns in earlier cases fell silent last

\footnotetext{
${ }^{33}$ Linda Greenhouse, Supreme Court Memo: At Supreme Court, 5-to-4 Rulings Fade, but Why? NY Times (May 23, 2008), online at http://www.nytimes.com/2008/05/23/us/23memo .html? pagewanted $=$ print.

${ }^{34}$ See Gerken, 68 Ohio St L J (cited in note 25) (noting the unstable middle on the Court in election law cases which has led to a "doctrinal interregnum").

${ }^{35}$ See Richard H. Pildes, Foreword: The Constitutionalization of Democratic Politics, 118 Harv L Rev 28 (2004). I should emphasize that advocates of the markets paradigm, such as Rick Pildes and Sam Issacharoff, do not suggest that competition should be the exclusive and outcome-determinative consideration in election law cases, just that it should play a stronger role. Nor would these scholars necessarily advocate a different result in each of the cases from last term, given the relevance of other considerations.
} 
term. Although one cannot describe this dog-not-barking as a strategic move to build broader coalitions, the general lack of attention to this type of argument explains, in just a small way, the muted dissent in some of these cases. It also illustrates the Roberts Court's reticence to question openly the motives of members of the political branches.

\section{A. THE PROMINENCE AND CHANGING NATURE OF AS-APPLIED CHALLENGES IN ELECTION LAW ${ }^{36}$}

Even as the body of the Court's term was still warm, commentators noticed a stylistic, if not substantive, shift in how the Court was treating the distinction between as-applied and facial challenges in election cases. ${ }^{37}$ Two of the Court's decisions from the term-Washington Grange and Crawford-upheld laws against facial challenges while explicitly reserving the question whether some as-applied challenge might be appropriate in a subsequent case. This approach is consistent with an earlier campaign finance case from the Roberts Court, Wisconsin Right to Life v FEC, ${ }^{38}$ which vindicated an as-applied challenge to the Bipartisan Campaign Reform Act, which the Rehnquist Court had upheld on its face only three years earlier. ${ }^{39}$ Those cases are also consistent with the Roberts Court's approach in certain nonelection cases, such as the two abortion cases it has decided, in which it upheld laws on their face while leaving open the possibility of later as-applied challenges. ${ }^{40}$

\footnotetext{
${ }^{36} \mathrm{~A}$ much longer discussion of the changing nature of as-applied doctrine in the recent election law decisions can be found in Nathaniel Persily and Jennifer Rosenberg, Defacing Democracy, Minn L Rev (forthcoming 2009).

${ }^{37}$ See Rick L. Hasen, About Face: The Roberts Court Sets the Stage for Shrinking Voting Rights, Putting Poor and Minority Voters Especially in Danger, FindLaw (Mar 26, 2008), online at http://writ.lp.findlaw.com/commentary/20080326_hasen.html; Dahlia Lithwick, Grandma Got Carded, Slate (Jan 9, 2008), online at http://www.slate.com/id/2181781/ pagenum/all/\#page_start (discussing oral arguments in Crawford, Lithwick notes, "With increasing frequency, the court's conservative wing has been chipping away at facial challenges (the better to bar litigation), and today Scalia takes out a sledgehammer: 'I mean, every facial challenge is an immense dictum on the part of this court, isn't it?' He goes on to characterize all facial challenges as the court 'sitting back and looking at the ceiling and saying, oh, we can envision not the case before us, but other cases . .."').

${ }^{38}$ WRTL, 127 S Ct 2652 (2007).

${ }^{39} \mathrm{Id}$ at 2673.

${ }^{40}$ See Ayotte v Planned Parenthood of Northern New England, 546 US 320 (2006); Gonzales $v$ Carhart, 550 US 124 (2007); Persily and Rosenberg, Minn L Rev (forthcoming 2009) (cited in note 36 ).
} 
The Washington Grange and Crawford cases are interesting in this respect because they appear to signal a shift at least in the way the Court discusses as-applied and facial challenges, if not in what the Court means by the distinction. In general, the standard approach to differentiating the two types of constitutional attack concerns whether the challenged law is alleged to be unconstitutional in all of its applications (the so-called Salerno ${ }^{41}$ standard for facial challenges) or simply as-applied to the plaintiff's unique circumstances. In last term's election law cases, though, the Court seemed to be conflating the as-applied/facial doctrine with doctrines of ripeness and justiciability. In both cases, the Court suggested that the law should be upheld on its face because the true extent of the constitutional burden remained unknown at the time of the litigation. In the future, when the burden of the law could be better understood, a proper as-applied challenge might lie.

In Washington State Grange v Washington State Republican Party, ${ }^{42}$ the Court upheld a nonpartisan primary law against a facial challenge because it was unclear whether the ballot would infringe on the parties' First Amendment rights. ${ }^{43}$ The law specified that any candidate could run in the primary, in which the top two votegetters, regardless of party, would advance to the general election ballot. But the law allowed the candidates to state a party preference that would appear next to their name on the primary and general election ballot. The parties sued because they would not have any control over which candidates, including some that might not even be party members, could use the parties' names on the ballot. The Supreme Court upheld the law on its face because the ballot would only violate the parties' associational rights if voters would be confused as to whether the "party preference" designation on the ballot signified endorsement of the candidate by the party. ${ }^{44}$ Because the ballot had not yet been designed, the Court could not determine that it would necessarily confuse voters into wrongly assuming party endorsement where none existed. ${ }^{45}$ It would be possible for the ballot to be especially clear that an " $R$ "

\footnotetext{
${ }^{41}$ United States $v$ Salerno, 481 US 739, 744 (1987) ("[T] he challenger must establish that no set of circumstances exists under which the Act would be valid.") (emphasis added).

${ }^{42} 128$ S Ct 1184 (2008).

${ }^{43}$ Id at 1195 .

${ }^{44} \mathrm{Id}$.

${ }^{45}$ Id at 1194.
} 
next to a candidate's name, for example, does not signify she is endorsed by the Republican Party. The law, therefore, was facially constitutional, even if it might be unconstitutional once the state had applied it in a concrete case. (As it turned out, the ballot notation for the 2008 election said "Prefers Republican Party" or "Prefers Democratic Party" under the candidate's name. ${ }^{46}$ )

Washington Grange provided a precedent the Crawford Court quickly followed in upholding Indiana's photo ID requirement. ${ }^{47}$ Given that no statewide election had been held under the new Indiana law, there was great uncertainty as to the number of people who would be unable to vote as a result of it. Although they alleged that 40,000 Indianans of voting age did not have acceptable forms of ID, the plaintiffs did not find a single person who said that the law would prevent her from voting. ${ }^{48}$ In what Justice Scalia's concurrence derided as a "record-based resolution of the case," 49 Justice Stevens's controlling opinion ${ }^{50}$ (joined by Chief Justice Roberts and Justice Kennedy) emphasized that the record was incomplete both as to the number of voters burdened by the ID requirement and as to the severity of the burden on those affected. ${ }^{51}$ In this sense, the Court, as in Washington Grange, upheld the law on its face because no constitutional injury had yet been proven based on the facts in the legislative or litigation history. ${ }^{52}$ If this is the correct way to read Crawford, then the voter ID law might be unconstitutional on its face once better evidence emerges

${ }^{46}$ See Sample Ballot-Kitsap County, Washington, online at http://www.kitsapgov.com/ aud/elections/archive/08/sample\%20ballot\%20gen\%202008.pdf.

${ }^{47}$ See Crawford v Marion County, 128 S Ct 1610, 1622 (2008) ("Our reasoning in that case [Washington Grange] applies with added force to the arguments advanced by petitioners in these cases.").

${ }^{48} 472$ F3d 949, 951-52 (7th Cir 2007).

${ }^{49}$ Crawford, $128 \mathrm{~S} \mathrm{Ct}$ at 1626 (Scalia concurring).

${ }^{50}$ The Court split into three equal camps in Crawford. Justice Stevens wrote the controlling opinion for himself, Justice Kennedy, and Chief Justice Roberts. Justice Scalia's concurrence was joined by Justices Alito and Thomas. Justices Souter, Ginsburg, and Breyer dissented.

${ }^{51} 128 \mathrm{~S} \mathrm{Ct}$ at 1622.

${ }^{52}$ The Court adopted a similar approach in Baze v Rees, 128 S Ct 1520 (2008), rejecting a facial challenge to the three-drug protocol Kentucky uses in its executions. The mere risk that the protocol might be misused in a way that led the condemned to suffer did not justify striking it down on its face. What an as-applied challenge to the method might look like in the future is somewhat difficult to contemplate, given that someone else besides the person "injured" by the misuse of the protocol would then need to bring the case. Perhaps the next person who is to be subjected to the protocol could bring an "as-applied" challenge based on what was learned from the previous mistake. 
as to the number of people who cannot or do not vote because of a lack of ID.

Crawford's emphasis on the distinction between facial and asapplied challenges, however, may mean something altogether different from the ripeness-style inquiry coming out of Washington Grange. A large section of the controlling opinion appears to apply the traditional view of the doctrine by rejecting plaintiffs' facial challenge but leaving open whether later plaintiffs could show a unique harm that justifies striking the law down as applied to them. The opinion refers to certain classes of voters, such as elderly people born out of state, homeless people, and others who might not have birth certificates, as populations likely to experience a "special burden on their right to vote." ${ }^{53}$ For those people, the law might impose an especially severe burden such that the state must make an exception to the ID requirement. The case of the nine elderly nuns who were turned away from the polls (by a fellow nun, incidentally) for lack of ID in the 2008 Indiana presidential primary might serve as an example of potential plaintiffs in a future case. ${ }^{54}$ Relying again on the deficiencies in the record, however, the Court suggested "it is not possible to quantify either the magnitude of the burden on this narrow class of voters or the portion of the burden imposed on them that is fully justified." ${ }^{55}$

In this respect, the decision treats the Indiana ID law as the Court treated Title II of the Bipartisan Campaign Reform Act (BCRA) in McConnell $v$ FEC ${ }^{56}$ and Wisconsin Right to Life v FEC

\footnotetext{
${ }^{53} 128 \mathrm{~S} \mathrm{Ct}$ at 1622.

${ }^{54}$ See Associated Press, Nuns with dated ID turned away at Ind. Polls (May 6, 2008), online at http://www.msnbc.msn.com/id/24490932/; Michael Scherer, 7 Things That Could Go Wrong on Election Day, Time (Oct 26 2008), online at http://www.time.com/time/specials/ packages/article/0,28804,1853246_1853243_1853238,00.html?imw $=$ Y. Great disagreement exists as to how many people do not vote or end up voting a provisional ballot as a result of strict voter ID laws. Survey research suggests that ID laws have little effect on turnout. See Ansolabehere, 63 NYU Annual Surv Am L (cited in note 12). Relying on interviews of county election officials, the one study of the effect of voter ID in Indiana estimated that approximately 400 people cast provisional ballots that went uncounted in the 2008 presidential primary because of ID problems. See Pitts, 24 J L \& Pol (forthcoming 2009) (cited in note 12). The state does not release data that classify provisional ballots by "cause," nor do they release information as to how many ballots cast because of ID problems go uncounted or how many people are turned away because of ID problems. Therefore, those attempting to establish the ID requirement as a significant barrier to voting or one that has a measurable disparate impact on distinct groups will face great difficulties.

${ }^{55} 129$ S Ct 1622.

${ }^{56} 540$ US 93 (2003).
} 
(WRTL). ${ }^{57}$ In McConnell, the Court rejected a facial challenge to the express advocacy provisions of the BCRA, which prohibited the use of corporate or union treasury money for television advertisements that "refer[red] to a clearly identified candidate" in the period immediately before a federal election. However, the Court left open the possibility in a footnote ${ }^{58}$ of later as-applied challenges that demonstrated unique burdens on the speech rights of certain corporate entities. The Court seemed to suggest that a corporate-funded advertisement that ran afoul of the law but was a genuine discussion of issues, rather than an attempt to influence an election, would be exempted from the law. Three years later the Roberts Court sustained such an as-applied challenge in WRTL so as to exempt a corporate-sponsored advertisement that mentioned two senators by name (one of whom would appear on the ballot) in the context of an admonition to call them to tell them to confirm Bush's judicial nominees. Most significantly for purposes of assessing the evolution of the "as-applied" jurisprudence, however, the Court did not merely exempt this particular ad. Rather, the as-applied challenge led to a rule that now limited the statute only to advertisements that are "susceptible of no reasonable interpretation other than as an appeal to vote for or against a specific candidate." ${ }^{59}$ Given that very few such ads are incapable of some other interpretation, the Court used this as-applied challenge to exempt most of the potential applications of the statute. ${ }^{60}$

\footnotetext{
${ }^{57} 127$ S Ct 2652 (2007).

${ }^{58} \mathrm{McConnell,} 540$ US at $157 \mathrm{n} 52$.

${ }^{59}$ WRTL, $127 \mathrm{~S} \mathrm{Ct}$ at 2667 . This creation of a rule pursuant to an as-applied challenge
} is all the more peculiar in the context of the BCRA, given that the statute included a backup "secondary definition" of electioneering communications that would be triggered if the primary definition were declared unconstitutional. The effect of WRTL was to redefine the primary definition of express advocacy without triggering the secondary definition and in effect rewriting a statute to produce regulatory language for which Congress never voted. See Persily and Rosenberg, Minn L Rev (forthcoming 2009) (cited in note 36).

${ }^{60}$ WRTL, $127 \mathrm{~S}$ Ct at $2684 \mathrm{n} 7$ (Scalia, J, concurring in part, concurring in the judgment) (arguing for facial invalidation and describing WRTL's controlling opinion as exercising "faux judicial restraint"). WRTL and Washington Grange's discussions of the as-applied/ facial distinction are peculiar in another respect. Both constituted First Amendment challenges to election laws. In general, the Salerno rule is relaxed in the First Amendment context because of the fear of a chilling effect on speech. See, for example, Ashcroft $v$ Free Speech Coalition, 535 US 234 (2002) (suggesting that a law will be facially unconstitutional if it prohibits a "substantial amount of protected speech"). These two cases almost appear to craft an election law exception to the general First Amendment overbreadth exception to facial challenges. 
If Crawford follows the formula of McConnell/WRTL, then discrete groups of individuals who have particular difficulty acquiring ID might be able to receive court-crafted exemptions from the law. Although still viable in theory, there is good reason to think plaintiffs will rarely bring or succeed with such challenges. Indeed, a federal court has already rejected one such as-applied challenge to the Indiana law, ${ }^{61}$ and the Eleventh Circuit has upheld a similar Georgia ID law without even mentioning the possibility of an asapplied challenge. ${ }^{62}$ Individuals who find it difficult to navigate the hurdles of getting an ID are unlikely to find a federal lawsuit to be an easier course to enfranchisement. And the parties, interest groups, and nonprofits that ordinarily bring such cases have little incentive to do so in this context, when the narrowness of any asapplied relief, especially if granted only after an election, is unlikely to extend to a significant group of people. There are only so many elderly voters who were born out of state, have significant difficulty getting birth certificates, and would prefer not to vote by absentee, for example-and litigation to gain an exception for that narrow class of people is unlikely to provide benefits that outweigh the costs. The chief burden on voting rights the ID requirement imposes is the cost and inconvenience of acquiring the necessary documents and then traveling to and waiting at the Bureau of Motor Vehicles to get an ID. For all practical purposes, the Court appears already to have decided that such a burden is not severe in the abstract, and it is difficult to define a class of people for whom the burden is uniquely severe to the point where the time and cost involved necessarily and inevitably will preclude them from voting. ${ }^{63}$ A capacious rule-like exception along the lines of WRTL seems already foreclosed by Crawford.

The Crawford Court's assessment of the burdens the ID law imposed (let alone the state's antifraud justification discussed later in this article) has as much to do with substantive voting rights doctrine as it does with the distinction between as-applied and

\footnotetext{
${ }^{61}$ See Stewart v Marion County, 2008 WL 4690984, *3 (SD Ind, Oct 21, 2008).

${ }^{62}$ See Common Cause/Georgia v Billups, No 07-14664 (11th Cir 2009), online at http:// www.ca11.uscourts.gov/opinions/ops/200714664.pdf.

${ }^{63}$ In other words, the most opponents could hope for is a ruling that strikes down the law, for example, as applied to poor people who find it very difficult to get the required documents, such as a birth certificate, to then get an ID. But "very difficult" is probably not good enough. Most people falling into that category conceivably can get such documents; they just will not do so merely for the trivial benefit of voting.
} 
facial challenges. ${ }^{64}$ To be sure, the as-applied ruling, insofar as it makes voting rights litigation more costly and less likely, represents a significant blow for voting rights advocates. ${ }^{65}$ Yet the principal problem with that holding, if there is one, would be the evolution away from a conception of the relevant constitutional balance that views hindrances with concentrated impacts on certain groups as the singular and historic inquiry involved in weighing state interests versus deprivations of voting rights. In Harper $v$ Virginia Board of Elections, for example, the Supreme Court struck down the poll tax on its face, not merely as applied to poor people. ${ }^{66}$ Voting laws that are unconstitutional on their face are usually so because a minority (even a nonsuspect one) is disadvantaged. This is not to say that any law that makes it more difficult for some people to vote is necessarily unconstitutional. Otherwise, voter registration itself, let alone reducing the number of polling places, would be facially unconstitutional ${ }^{67}$ However, the inquiry as to the facial constitutionality of the law must necessarily be about justifying the burdens on the minority for whom the "neutral" law presents a disparate impact.

The WRTL, Washington Grange, Crawford triumvirate may signal a shift in the way the Roberts Court treats the as-applied/facial distinction in election law cases. The distinction between facial and as-applied challenges, which had always been the subject of

${ }^{64}$ See Michael C. Dorf, Facial Challenges to State and Federal Statutes, 46 Stan L Rev 235, 294 (1994) (suggesting the distinction between as-applied and facial challenges is largely dependent on the appropriate test determined by substantive doctrine).

${ }^{65}$ The effects may already be seen in Florida Conference of the NAACP $v$ Browning, 2008 WL 2567204 (ND Fla 2008) (rejecting facial challenge to Florida's "no match, no vote" law).

${ }^{66}$ See Harper v Virginia Bd of Elections, 383 US 663 (1966). The Crawford Court tried to distinguish Harper by suggesting that, unlike there, an election-related state interest (preventing fraud) justifies the Indiana ID rule and a poll tax was unrelated to voter qualifications. See Crawford, $128 \mathrm{~S}$ Ct at 1615; see also id at 1624 \& n 1 (Scalia, J, concurring) ("[W]e have never held that legislatures must calibrate all election laws, even those totally unrelated to money, for their impacts on poor voters or must otherwise accommodate wealth disparities."). Of course, the proponents of the poll tax thought it was very relevant to voter qualifications. One might also ask whether, as to the state justification, the tax would then be constitutional if used to fund elections. Implicitly, perhaps, the Court is also reaffirming the constitutionality of literacy tests, which it upheld in Lassiter $v$ Northampton County Board of Elections, 360 US 45 (1959), and has never repudiated, even though the Voting Rights Act later made such tests illegal. One could easily make arguments as to the importance of literate voters for the integrity of elections.

${ }^{67} 128 \mathrm{~S} \mathrm{Ct}$ at 1626 (Scalia, J, concurring) (discussing the potential implication of striking down voter ID for the constitutionality of all types of election laws). 
debate ${ }^{68}$ may simply be breaking down with these cases, as well as others the Court has decided. ${ }^{69}$ At times the Court deploys the distinction between the two types of constitutional attack in order to avoid explicitly overturning precedent $(W R T L)$; in others it does so to craft greater consensus by focusing on deficiencies in the record (Crawford) or the ripeness of the case (Washington Grange and Crawford). The WRTL/McConnell pairing illustrates how judicially crafted "as-applied" exceptions can swallow legislative rules. Washington Grange and one interpretation of Crawford appear to hold open the promise of a future "as-applied" challenge, which, now based on full knowledge of the law's effects, might lead to a finding of facial unconstitutionality. Finally, the interpretation of Crawford that emphasizes a carve-out for potentially disadvantaged groups points toward as-applied challenges that are theoretically available but extremely unlikely.

These three cases, as well as the abortion cases the Court has decided, have delivered ammunition to critics who claim that the "passive virtue" of minimalism through incremental as-applied challenges is sometimes neither passive nor virtuous. ${ }^{70}$ The strategy can be quite activist, as WRTL illustrates, when employed in a constitutional domain where the opinion's author cares deeply about the rights at issue. In other contexts, where the rights implications are deemed less severe (Crawford and Washington Grange, perhaps), the illusory promise of future as-applied challenges can be a bone to throw to Justices who might otherwise dissent or to litigants ever hopeful that they might find the extraordinary case with the right set of facts where narrow relief is both desirable and warranted. In each case, the choice made at this branch on the constitutional decision tree almost always reflects some position as to the desired outcome in such cases, in general. Thus, while we may concentrate on the significance of favoring one type of constitutional attack over another, this debate often represents a proxy war of sorts over the central constitutional values at stake.

\footnotetext{
${ }^{68}$ Compare Richard Fallon, As-Applied and Facial Challenges and Third Party Standing, 113 Harv L Rev 1321, 1324 (2000) (suggesting all constitutional challenges "are in an important sense, as-applied"), with Matthew D. Adler, Rights Against Rules, 97 Mich L Rev 1, 157 (1998) (arguing there is "no such thing as a true as-applied constitutional challenge").

${ }^{69}$ See Baze v Rees, 128 S Ct 1520 (2008); Carhart v Gonzalez, 127 S Ct 1610, 1639 (2007); Ayotte v Planned Parenthood of Northern New England, 546 US 320 (2006).

${ }^{70} \mathrm{I}$ am indebted to Pam Karlan for this quip.
} 


\section{B. THE LACK OF CONCERN FOR ANTICOMPETITIVE ELECTION LAWS}

One other argument that the Crawford majority found irrelevant was the contention that the voter ID law represented an effort by a Republican legislature to place barriers in the way of Democratic voters. Such an argument has been a staple of both election law litigation and academic discussion in recent years (even if rarely commanding a Court majority), with proponents advocating a greater role for courts in reining in efforts at entrenchment by parties and incumbent politicians. ${ }^{71}$ In one election law context or another, every Justice on the Roberts or Rehnquist Court has signed on to such a theory, even though none would subscribe to it consistently across election law. The argument, dubbed "politics as markets" by some,${ }^{72}$ maintains that the traditional rights-based focus of election law cases ought to be relaxed in favor of an approach that concentrates on removing barriers to political competition and controlling self-interested moves made by incumbents to entrench themselves. Such concerns were absent from any majority opinion, which is worth recognizing given that at least three cases-Crawford, Davis, and Lopez Torres ${ }^{73}$ - squarely presented the issue.

For those who worry about one party using its monopoly to hobble the competitive position of its adversary by tinkering with voter eligibility, Crawford provided a perfect opportunity to express that concern. Indeed, Judge Evans's dissent from the Seventh Circuit panel decision that upheld the ID law made the point bluntly. "Let's not beat around the bush," he wrote. "The Indiana voter photo ID law is a not-too-thinly-veiled attempt to discourage elec-

\footnotetext{
${ }^{71}$ See Nathaniel Persily, The Place of Competition in American Election Law, in Michael P. McDonald and John Samples, eds, The Marketplace of Democracy: Electoral Competition and American Politics 172-74 (Brookings, 2006) (summarizing academic discussion and caselaw).

${ }^{72}$ See Samuel Issacharoff and Richard H. Pildes, Politics as Markets: Partisan Lockups of the Democratic Process, 50 Stan L Rev 643 (1998); Richard H. Pildes, Foreword: The Constitutionalization of Democratic Politics, 118 Harv L Rev 28, 55 (2004); Samuel Issacharoff, Gerrymandering and Political Cartels, 116 Harv L Rev 593, 642-43 (2002).

${ }^{73}$ See Lopez Torres v N.Y. State Bd of Elections, 462 F3d 161 (2d Cir 2006) (observing that "[s]ince 1944 New York's judicial nominating system has been described as exclusionary and boss-dominated; reports and newspaper editorials from that time forward have decried an electoral practice 'that mocks choice,' and criticized a system in which 'voters can never know the candidates and have to accept party slates,' while the 'real choice is left to political bosses . . . who control nominations"”).
} 
tion-day turnout by certain folks believed to skew Democratic."74 Just as one party might be able to tip the electoral scales in its favor through partisan gerrymandering or restrictive ballot access rules, so too it could tailor barriers to entry to ensure some of its opponents' supporters will have difficulty voting.

The argument did not resonate with anyone on the Supreme Court, however. Given his frequent expression of this concern in the context of gerrymandering, ${ }^{75}$ ballot access,${ }^{76}$ and regulation of political parties, ${ }^{77}$ Justice Stevens might have been thought to be receptive to this argument. Yet his opinion in Crawford, like Justice Scalia's concurrence, refused to look behind the state's proffered antifraud interests to unearth partisan motivation. " $\mathrm{I}] \mathrm{f}$ a nondiscriminatory law is supported by valid neutral justifications," Stevens wrote, "those justifications should not be disregarded simply because partisan interests may have provided one motivation for the votes of individual legislators." ${ }^{78}$ Because he placed great weight on the legitimacy of the state's proffered antifraud interest and therefore did not view partisan interests as the only justification for the ID law, the unanimous support of Republican legislators and unanimous opposition by Democrats was irrelevant to the constitutionality of the statute. Even the dissenters who would have struck down the law would not have done so because of nascent partisan motivation. ${ }^{79}$

${ }^{74}$ See Crawford v Marion County Election Bd, 472 F3d 949, 954 (7th Cir 2007) (Evans dissenting).

${ }^{75}$ See League of United Latin American Citizens v Perry, 548 US 399, 458 (2006) (Stevens, J, dissenting); Vieth v Fubelirer, 541 US 267, 332-33 (2004) (Stevens, J, dissenting) ("when partisanship is the legislature's sole motivation-when any pretense of neutrality is forsaken ... - the governing body cannot be said to have acted impartially."); Karcher v Daggett, 462 US 725 (1983) (Stevens, J, concurring).

${ }^{76}$ See Timmons v Twin Cities Area New Party, 520 US 351, 378 (1997) (Stevens, J, dissenting) (arguing that the intent of an antifusion law to promote the two-party system ought to weigh against the constitutionality of the law).

${ }^{77}$ See Clingman v Beaver, 544 US 581, 614 (2005) (Stevens, J, dissenting).

${ }^{78}$ Crawford, $128 \mathrm{~S} \mathrm{Ct}$ at 1624 . Stevens's position in Crawford may not be as surprising as I suggest, given his general aversion to purpose-based tests. See, for example, Washington $v$ Davis, 426 US 229, 252, 254 (1976) (Stevens, J, concurring) ("the line between discriminatory purpose and discriminatory impact is not nearly as bright, and perhaps not quite as critical, as the reader of the Court's opinion might assume").

${ }^{79}$ Justice Souter emphasized that " $[\mathrm{t}] \mathrm{ens}$ of thousands of voting-age residents lack the necessary photo identification" and "[a] large proportion of them are likely to be in bad shape economically" yet did not argue that such residents were more likely to be Democrats. See Crawford, 128 S Ct at 1638 (Souter dissenting). Justice Breyer would have found the law unconstitutional because it "imposes a disproportionate burden upon those eligible voters who lack a driver's license or other statutorily valid form of photo ID." 
The anticompetitive impact of the nomination method for New York judicial elections was the issue in New York State Board of Elections $v$ Lopez Torres. ${ }^{80}$ The district court and Second Circuit panel that had struck down the hybrid system of a primary election to send delegates to a convention did so because of the determinative and unchecked power wielded by party leaders at the convention to choose the party's judicial nominees. ${ }^{81}$ They argued that the election of delegates to those conventions was meaningless given that party bosses ended up wielding their informal, yet coercive, power to force the convention to ratify their wishes. Because virtually all judicial districts favor one party or the other, the nomination exists as the determinative selection process for who will be a trial court judge.

Justice Scalia's opinion for the Court expressly rejected the political markets argument in the context of the judicial nomination system and perhaps more broadly. Both his opinion for the Court and Justice Kennedy's concurrence maintained that the option of running as an independent candidate was an adequate safeguard to protecting the right of a potential candidate to run for office. ${ }^{82}$ The Court refused to look at the functionally monopolistic power the parties wielded in selecting judges for each judicial district. The fact that a general election in a politically homogeneous district was almost always a meaningless exercise once the party had selected the nominee did not change the constitutional calculus. The First Amendment, the decision held, "does not call on the federal courts to manage the market [for political ideas] by preventing too many buyers from settling upon a single product." ${ }^{\prime 3}$

Campaign finance is the one context in which a majority of the current Court (though not in a single decision) has signed on to the principle that the Constitution requires an inquiry into a reg-

\footnotetext{
${ }^{80} 128$ S Ct 791 (2008).

${ }^{81}$ Lopez Torres v N.Y. State Bd of Elections, 462 F3d 161, 200-01 (2d Cir 2006) (“[T]hrough a byzantine and onerous network of nominating phase regulations employed in areas of one-party rule, New York has transformed a de jure election into a de facto appointment. '[I]n every practical sense,' these regulations preclude all but candidates favored by party leadership 'from seeking the nomination of their chosen party, no matter how qualified they might be, and no matter how broad or enthusiastic their popular support.'") (internal citations omitted); Lopez Torres v New York State Bd of Elections, 411 F Supp 2d 212, 255 (EDNY 2006) ("[T] which party leaders, rather than the voters, select the Justices of the Supreme Court.").

${ }^{82}$ Lopez Torres, $128 \mathrm{~S} \mathrm{Ct}$ at 801; id at 803 (Kennedy, J, concurring).

${ }^{83} \mathrm{Id}$ at 801 .
} 
ulation's effect on political competition. The strongest advocates for the anti-entrenchment approach have been Justices Scalia and Thomas, who repeatedly warn against the risk that incumbents will craft campaign finance laws that insulate themselves from competition. ${ }^{84}$ In Randall $v$ Sorrell, ${ }^{85}$ a controlling opinion for the Court, for the first time, struck down a campaign finance lawVermont's stringent limit on contributions-because of its anticompetitive impact on challengers. ${ }^{86}$ The decision even went so far as to state explicitly that the constitutionality of contribution limits depends on whether they "magnify the advantages of incumbency to the point where they put challengers to a significant disadvantage." 87

No language similar to that in Randall can be found in the Court's opinion in Davis. Despite the clunkiness of doing so given the strange character of the Millionaire's Amendment, the Davis decision reads like a formulaic campaign finance decision. The Court inquired whether the law was a limitation on contributions or expenditures, the former raising less of a constitutional problem than the latter. Once it concluded that the Millionaire's Amendment restricted expenditures, because it punished self-financed candidates by allowing their opponents (and only their opponents) to raise contributions treble the normal limits, ${ }^{88}$ the Court searched and failed to find a compelling state interest to justify it. No interest in preventing corruption or the appearance of corruption justified this law, and the proffered state interest in "level[ling] electoral opportunities" might not even have been le-

\footnotetext{
${ }^{84}$ See McConnell v FEC, 540 US 93, 249-50 (2003) (Scalia, J, dissenting) (“As everyone knows, this is an area where evenhandedness is not fairness. . . [A]ny restriction upon a type of campaign speech that is equally available to challengers and incumbents tends to favor incumbents."); Colorado Federal Campaign Committee v Federal Election Com'n, 518 US 604, $644 \mathrm{n} 9$ (1966) (Thomas, J, dissenting) ("There is good reason to think that campaign reform is an especially inappropriate area for judicial deference to legislative judgment. What the argument for deference fails to acknowledge is the potential for legislators to set the rules of the electoral game so as to keep themselves in power and to keep potential challengers out of it.") (citations omitted).

${ }^{85} 548$ US 230 (2006).

${ }^{86} \mathrm{Id}$ at 237.

${ }^{87} \mathrm{Id}$ at 248.

${ }^{88}$ Davis, 128 S Ct at 2771 (The BCRA "imposes an unprecedented penalty on any candidate who robustly exercises that First Amendment right [to spend personal funds for campaign speech].").
} 
gitimate, let alone compelling. ${ }^{89}$ Therefore, the law violated the First Amendment.

The absence of a discussion of the law's effect on competition is particularly striking because plenty of statements in the legislative record hint at the pro-incumbent bias of the Millionaire's Amendment. ${ }^{90}$ As Senator Harry Reid plainly said in the debate over the Amendment: "It has nothing to do with millionaires. It has everything to do with protecting us. It is an incumbent advantage measure in this underlying bill." ${ }^{\prime 1}$ Or as Congressman Tom Reynolds warned, "My colleagues should live in fear, all 435 of us, that a wealthy American decides to run." 92 Even Senator John McCain, who authored the BCRA and reluctantly accepted the Millionaire's Amendment, admitted the provision would pass because "everyone [was] scared to death of waking up one morning and reading in the newspaper that some Fortune 500 C.E.O. or heiress is going to run against them." 93 Yet for the Court, no word appears about entrenchment; the law simply impaired speech without any good justification. ${ }^{94}$

${ }^{89} \mathrm{Id}$ at 2773 . The Court also rejected the state interest in preventing the perception that offices are for sale to the highest bidder.

${ }^{90}$ Brief of Gene DeRossett and J. Edgar Broyhill II as Amici Curiae Supporting Appellant at 13, 26-27 n 15, Davis, 128 S Ct 2759 (No 07-320) (quoting legislative history); Robert Bauer, The Travails of Reform, in Its Encounters with the Very Wealthy, More Soft Money Hard Law (Aug 16, 2006), online at http://moresoftmoneyhardlaw.com/moresoftmoneyhardlaw/updates/ federal_candidates_officeholders.html?AID =794 ("The Millionaire's Amendment-meant to provide some protection for opponents of the rich, 'self-financed' candidate-is straightforward in purpose and design. It is born of much fretting about the danger presented to incumbency by rich people.").

${ }^{91} 147$ Cong Rec S 2845-02, S 2852 (Mar 26, 2001) (statement of Sen. Harry Reid in opposition to BCRA).

${ }^{92} 148$ Cong Rec H 256-03, H 261 (Feb 12, 2002) (statement of Rep. Thomas Reynolds, opposing the House version of BCRA because the Millionaire's Amendment did not go far enough to protect incumbents).

${ }^{93}$ Alison Mitchell, Senate Votes to Aid Candidates Facing Deep Pockets, NY Times A16 (Mar 21, 2001).

${ }^{94}$ Professor Richard Pildes suggests that, although it goes unmentioned, the animating force of the majority opinion must be its concern about entrenchment. See Rick Pildes, When Do Campaign Finance Laws Become a Way to Protect Incumbents? Balkinization (June 26, 2008), online at http://balkin.blogspot.com/2008/06/sympathy-for-millionaire-self .html ("And a key aspect to this case is only hinted at in the Court's opinion but nonetheless undoubtedly shapes the decision: the enormous risk that this provision-and others like it Congress might adopt-is a way for incumbents to manipulate election laws so as to make it even harder for challengers to take them on.”). I am not sure I even see the hints. Nevertheless, it takes great effort to do so, whereas, in other opinions, such as Justice Scalia's dissent in McConnell, the point is made explicit. This alleged sub silentio adoption of the markets approach is all the more remarkable given that the Court reached out in Randall $v$ Sorrell to strike down the law because of its anticompetitive effect, even though 
To find some glimmer of the political markets approach, one would need to look to the dissent, not the majority opinion. Writing only for himself, Justice Stevens begins his opinion with a radically authoritarian view of the lack of First Amendment protection available for campaign speech. ${ }^{95} \mathrm{He}$ would have upheld both the law's contribution limits and its limits on expenditures. In the part of his dissent joined by three others, however, he warns about the effect of wealth on political competition. ${ }^{96} \mathrm{He}$ views the Millionaire's Amendment as attempting "to reduce the distinct advantages enjoyed by wealthy candidates for congressional office." ${ }^{97}$ The provision, under this view, promoted rather than hindered competition by diminishing the ability of wealthy candidates to buy their election. Although the dissent does not speak of incumbency or entrenchment, per se, it does view the measure as quite explicitly promoting a more competitive electoral playing field. For the majority, if anything, that was precisely the problem.

The absence of a majority opinion in these cases that takes the political competition argument seriously is not unique to last term. Apart from Randall, the argument remains one more often made in dissent, whether by Justices or academics. Nevertheless, the Court's possibly calculated decision not to peek behind the veil of the proffered state interests to view a background of political avarice and partisanship attests to a strategy of avoiding more open conflict with the political branches. The point may be more stylistic than anything else, but in the post-Bush $v$ Gore era (or perhaps the post-Rehnquist Court era) a retreat from aggressively analyzing the motives of politicians is worth noting.

\section{Reading the Tea Leaves in the Roberts Court's Election Law Decisions: The Signals from the 2007-2008 Term for What Lies Ahead}

Despite its infancy, the Roberts Court has now issued opin-

no one plausibly argued the contribution limits there were motivated by incumbent entrenchment.

${ }^{95}$ Davis, $128 \mathrm{~S}$ Ct at 2779 (Stevens, J, concurring in part, dissenting in part) (arguing that rules for election spending by candidates ought to be similar to rules for speaking by litigants in court).

${ }^{96} \mathrm{Id}$ at 2781 ("[W]e have long recognized the strength of an independent governmental interest in reducing both the influence of wealth on the outcomes of elections, and the appearance that wealth alone dictates those results.").

${ }^{97}$ Id at 2782. 
ions in each of the major categories of election law: campaign finance, voting rights, regulation of political parties, and redistricting. It also will soon hear major cases dealing with the meaning and constitutionality of the Voting Rights Act, ${ }^{98}$ as well as two additional campaign finance cases, one of which also deals with judicial elections. ${ }^{99}$ Thus far the Court has only struck down campaign finance laws (all three it has considered) and one district at issue in the Texas gerrymandering case. ${ }^{100}$ In all other cases, the Court has upheld the election laws it has reviewed. It should therefore come as no surprise that the future looks bleak for campaign finance regulation, complicated for cases concerning race and redistricting, but hopeful for jurisdictions crafting election laws for most other areas.

\section{A. CAMPAIGN FINANCE}

Campaign finance is the area of election law where the Roberts Court has made its most significant mark to date. In particular, the replacement of Chief Justice Rehnquist and Justice O'Connor, who often voted to uphold campaign finance laws, with Chief Justice Roberts and Justice Alito, who have proven to be more libertarian in campaign finance cases, has led to a solid five-member coalition that appears skeptical of campaign finance regulations. The Roberts Court has struck down all three campaign finance laws it has considered: Vermont's contribution and expenditure limits in Randall, the application of the BCRA to certain corporate campaign ads in WRTL, and the Millionaire's Amendment in Davis.

From Buckley $v$ Valeo ${ }^{101}$ until Randall v Sorrell, ${ }^{102}$ contribution

${ }^{98}$ See Bartlett v Strickland, 2009 WL 578634; Northwest Austin Mun. Util. Dist. No. One $v$ Mukasey, 573 F Supp 2d 221 (DDC 2008), prob juris noted (US Jan 9, 2009) (No 08$322)$.

${ }^{99}$ See Citizens United v Federal Election Commission, No 07-2240 (probable jurisdiction noted Nov 14, 2008) (addressing whether corporate-sponsored films critical of Hillary Clinton and Barack Obama would violate the "electioneering communications" provision of the BCRA as interpreted by the Court in McConnell and WRTL); Caperton v A.T. Massey Coal Co., No 08-22 (cert granted Nov 14, 2008) (addressing whether a judge who has accepted donations from an individual or firm involved in a case before his court must be disqualified on due process grounds).

${ }^{100}$ See Davis v FEC, 128 S Ct 2759, 2774 (2008); WRTL, 127 S Ct 2652 (2007); Randall v Sorrell, 548 US 230 (2006); LULAC, 548 US 399 (2006).

101424 US 1 (1976).

${ }^{102} 548$ US 230 (2006). 
limits appeared almost untouchable by the Supreme Court. Once the state justified a law as motivated by a desire to combat corruption or its appearance, the only question remained whether the law, in effect, prevented a candidate from "amass[ing] the resources necessary for effective advocacy." 103 Until Randall, the Court had little difficulty giving great deference to Congress and state legislatures on both the problem of corruption and the propriety of contribution limits to prevent it. Jurisdictions could feel relatively secure that, even with the flimsiest evidence of corruption or its appearance, contribution limits would be upheld. ${ }^{104}$ Randall, for the first time, placed an unsteady "lower bound" on how far contribution limits could go, by asking "whether [such limits] magnify the advantages of incumbency to the point where they put challengers to a significant disadvantage." ${ }^{105}$ Given that Vermont's limits were the lowest in the nation, as well as a variety of other factors, ${ }^{106}$ the controlling opinion for the Court (written by Justice Breyer but joined in full only by Chief Justice Roberts and in part by Justice Alito) found the limits were not "closely drawn" to address the state's interests in preventing corruption or its appearance.

The increased scrutiny of what had been thought to be a safe regulatory option invites inquiry as to whether the fundamental tenets of the Buckley framework have become destabilized. In addition to Randall, both Davis and WRTL have challenged some of the assumptions that guided the doctrinal development from Buckley through McConnell. The pillars of campaign finance doctrine until these recent decisions were judicial acquiescence to limits on individual contributions and to bans on corporate treasury expenditures on candidate campaigns, along with a general skepticism of regulations of individual expenditures.

A majority of the current Court, as with the Rehnquist Court,

${ }^{103}$ See Nixon v Shrink Missouri Gov't PAC, 528 US 377, 395 (2000) (quoting Buckley v Valeo, 424 US 1, 21 (1976)).

${ }^{104}$ See Nixon, 528 US 377.

${ }^{105}$ Randall v Sorrell, 548 US 230, 248 (2006).

${ }^{106}$ For example, the opinion added that the contribution limits would hinder political parties' ability to target their contributions to competitive races, and would generally reduce the voice of political parties "to a whisper." Id at 253, 254, 256, 257. It also pointed out that the Vermont law did not adjust the contribution limits for inflation, that they were the lowest in the nation, and that many volunteer services were considered contributions. Id at 261, 250. 
has stated a desire to overturn Buckley $v$ Valeo, but different Justices would overturn it for diametrically opposed reasons. Both Justice Stevens and Justice Ginsburg have written or joined opinions that say the First Amendment ought not stand in the way of regulating individual expenditures, as well as contributions. ${ }^{107}$ At least three and possibly four votes exist on the current Court to overturn Buckley's holding regarding the lesser scrutiny applied to contribution limits. In Randall itself, as well as earlier cases, Justices Thomas, Scalia, and Kennedy railed against the Buckley framework. They would subject both contribution and expenditure limits to strict scrutiny. Justice Alito's position has been slightly more cryptic, but his opinions in Randall and in Davis point in a skeptical direction. In Randall, his separate, partial concurrence went out of its way to emphasize that the parties had not requested the Court to reexamine Buckley. ${ }^{108}$

Furthermore, Justice Alito's opinion for the Court in Davis had some pretty disparaging things to say about the federal contribution limits. As suggested above, the Court's opinion there tries to take the square peg of the Millionaire's Amendment and fit it into the round hole of the Buckley doctrine. That provision did nothing to limit the expenditures of a self-financer, even if it indirectly penalized him by making it easier for his opponent to raise more money. Rather than curtailing the speech rights of candidates-indeed, it enabled more speech-the primary constitutional problem with the Millionaire's Amendment was that it undermined the justification for the contribution limits in an ordinary election. If the contribution limits could be raised when a candidate confronted a self-financer, Justice Alito suggested, then why are those limits closely drawn to prevent corruption in the normal case ${ }^{109}$ In other words, although the constitutionality of the federal limits was not before the Court, the existence of the exception for millionaire opponents was a problem because it re-

${ }^{107}$ See Nixon v Shrink Mo. Govt PAC, 528 US 377, 398 (Stevens, J, concurring); Colorado Republican Federal Campaign Committee v Federal Election Commission, 518 US 604, 648 (1996) (Stevens, J, dissenting).

${ }^{108}$ See id at 263 (Alito, J, concurring).

${ }^{109}$ See Davis v FEC, 128 S Ct 2759, 2774 (2008) ("If the normally applicable limits on individual contributions and coordinated party contributions are seriously distorting the electoral process, if they are feeding a 'public perception that wealthy people can buy seats in Congress,' and if those limits are not needed in order to combat corruption, then the obvious remedy is to raise or eliminate those limits.") (internal citation omitted). 
quired an explanation for why that exception should not ordinarily be the rule.

Finally, Justice Alito discussed Buckley and its progeny as sustaining "the facial constitutionality of limits on discrete and aggregate individual contributions and on coordinated party expenditures."110 That line would appear gratuitous if not for the strategy of WRTL to undo McConnell through as-applied challenges. Perhaps it signals some future analogous move to use Randall and Davis to chip away incrementally at the federal contribution limits. One should note that only Chief Justice Roberts and Justice Alito join together in the as-applied holding of WRTL; the three others who help form the majority would have reversed $M c$ Connell and struck the electioneering communications provisions down on their face. Moreover, Justice Alito also wrote separately in WRTL to emphasize that if as-applied litigation proves unworkable, the Court should strike down the electioneering provisions on their face. ${ }^{111}$

If this analysis is correct, then Chief Justice Roberts alone stands in the way of a fundamental alteration of the constitutional doctrine of campaign finance. Only he joined in full the controlling opinions in WRTL, Randall, and Davis. All of those opinions bend over backwards to justify their results in terms of stare decisis, ${ }^{112}$ even as critics sometimes pointed out the tortured logic thereby needed to overturn a large amount of the Buckley framework while treating other aspects as binding precedent. ${ }^{113}$ If followed, his approach would suggest a gradual erosion of the "pro-regulation" aspects of the Buckley framework, namely, the lower scrutiny otherwise accorded contribution limits and corporate treasury expenditures in candidate elections. In Citizens United $v F E C,{ }^{114}$ a case slated for the upcoming term, we may get some answers as to the impact of $W R T L$, as well as some guidance as to its effect on the disclosure regime forced upon organizations that spend corporate treasury funds. That case asks whether a corporate trea-

\footnotetext{
${ }^{110}$ Id at 2770.

${ }^{111}$ WRTL, 127 S Ct 2652, 2674 (2007) (Alito, J, concurring).

${ }^{112}$ Id at 2664-72; Randall v Sorrell, 548 US at 243; Davis v FEC, $128 \mathrm{~S}$ Ct at 2770-74.

${ }^{113}$ WRTL, $127 \mathrm{~S}$ Ct at 2674-87 (Scalia, J, concurring in part, concurring in the judgment); Randall, 548 US at 265-66 (Thomas, J, concurring in the judgment); Richard Hasen, Beyond Incoberence: The Roberts Court's Deregulatory Turn in FEC v. Wisconsin Right to Life, 92 Minn L Rev 1064 (2008) (noting the tension between McConnell and WRTL).

${ }^{114}$ No 07-2240 (probable jurisdiction noted Nov 14, 2008).
} 
sury-funded movie attacking Hillary Clinton during the 2008 primary campaign, as well as television ads marketing the movie, constitute protected issue advocacy or electioneering. The appellants there explicitly ask the Court to overrule its landmark decision in Austin $v$ Michigan Chamber of Commerce, ${ }^{115}$ which allowed for distinctive regulation of corporate electioneering activities. Moreover, the Republican Party has just filed an as-applied challenge to the soft money ban that was upheld in McConnell; ${ }^{116}$ if that and the Citizens United appeal prove to be successful, then the basics of the post-Buckley regime are likely to unravel.

To return to the theme that began this article, it is also likely that the campaign finance developments of the 2008 election will not be lost on the Court. Barack Obama's unprecedented \$750 million, 4-million-donor campaign ${ }^{117}$ may have broken the stereotypes as to who is favored by a system of private financing of campaigns. The election may curtail further reform efforts, now that an unlikely candidate supported by mass participation has greatly benefited from private contributions, but its effect on the relevant constitutional questions is difficult to predict. The proregulationists may point to this election as evidence that a popular candidate can run a competitive campaign even when contributions are capped at relatively low amounts. Campaign finance libertarians, on the other hand, may point to this election as evidence of the irrationality of contribution limits at all. If a candidate can raise hundreds of millions of dollars through the internet, how can it be that contributions in excess of the federal limit of $\$ 2,300$, for example, present a risk of corruption?

\section{B. REDISTRICTING AND THE VOTING RIGHTS ACT}

Redistricting cases rivaled campaign finance to constitute the largest share of the election law docket of the Rehnquist Court. Although occasionally dealing with heretofore unresolved ques-

115495 US 652 (1990). According to campaign finance expert Robert Bauer, this case "has the potential to leave a large and ever widening crack in the foundation of contemporary campaign finance regulation." See Robert Bauer, Citizens United: The Olson Brief, online at http://www.moresoftmoneyhardlaw.com/updates/outside_groups.html?AID = 1404 .

${ }^{116}$ See Editorial: Campaign finance on trial, again, Wash Times (Nov 13, 2008), online at http://www.washingtontimes.com/news/2008/nov/13/campaign-finance-on-trial-again/ (describing lawsuit).

${ }^{117}$ See Jeanne Cummings, Obama, the billion dollar man, Politico (Dec 2, 2008), online at http://www.politico.com/news/stories/1208/16115.html. 
tions concerning partisan gerrymandering, ${ }^{118}$ the Rehnquist Court considered a broad array of cases concerning the use and overuse of race in the redistricting process. Those cases came in the form of challenges to districting plans based on the Voting Rights Act $(\mathrm{VRA})^{119}$ or the constitutional prohibition on excessively racebased districts (the so-called Shaw line of cases). ${ }^{120}$ The Roberts Court has issued opinions in two such cases, Riley $v$ Kennedy ${ }^{121}$ from last term, and $L U L A C v$ Perry ${ }^{122}$ the Texas gerrymandering case from two terms earlier. It will also hear two VRA cases in the upcoming term: Bartlett $v$ Strickland,${ }^{123}$ which asks whether the VRA sometimes requires the creation of minority districts where minorities cannot form a majority, and Nortbwest Austin Municipal Utility District Number One v Holder, ${ }^{124}$ which challenges the constitutionality of Section 5 of the VRA.

If the Rehnquist Court was really the O'Connor Court when it came to constitutional questions concerning race, ${ }^{125}$ then the

${ }^{118}$ See Davis v Bandemer, 478 US 109 (1986); Vieth v fubelirer, 541 US 267 (2004). Although the Roberts Court considered the issue of partisan gerrymandering in LULAC, 548 US 399 (2006), it did not rule such claims nonjusticiable nor did it come up with a standard for when such gerrymanders are unconstitutional. Justice Kennedy's opinion in Vieth remains the "law," in that such claims are justiciable but no standard exists to adjudge their constitutionality. The 2006 and 2008 elections probably put a nail in the coffin for future partisan gerrymandering claims, which had never been on more than life support. The fact that the Democrats were able to capture Congress in 2006 and extend their margin in 2008 despite aggressive Republican gerrymanders has added greater credibility to the claims that partisan gerrymanders are self-correcting and judicial venturing into this political thicket is unnecessary and perhaps counterproductive. Some consider partisan gerrymanders to be self-correcting because the more aggressive the line-drawing party is in spreading its supporters, the greater the risk that a small shift in voters leads to a loss of a great number of seats. See Davis v Bandemer, 478 US 109, 152-55 (1986) (O'Connor, $\mathrm{J}$, concurring) (making such an argument as a basis for finding such claims nonjusticiable). As it turns out, Democrats picked up seats across states with redistricting plans that presented a variety of partisan or incumbent biases. However, in the face of the Republican gerrymander in Pennsylvania that gave rise to Vieth, the Democrats captured five Republican-held seats, such that they now hold twelve of the nineteen seats in the delegation.

${ }^{119}$ See, for example, Georgia v Ashcroft, 539 US 461 (2003); Reno v Bossier Parish School Board, 528 US 320 (2000); Fobnson v DeGrandy, 512 US 997 (1994).

${ }^{120}$ See, for example, Shaw $v$ Reno, 509 US 630 (1993); Miller $v$ fohnson, 515 US 900 (1995); United States v Hays, 515 US 737 (1995); Shaw v Hunt, 517 US 899 (1996); Bush v Vera, 517 US 952 (1996); Hunt v Cromartie, 526 US 541 (1999); Easley v Cromartie, 532 US 234 (2001).

${ }^{121} 128$ S Ct 1970 (2008).

122548 US 399 (2006).

${ }^{123} 2009$ WL 578634.

${ }^{124}$ Northwest Austin Mun. Util. Dist. No. One v Mukasey, 573 F Supp 2d 221 (DDC 2008), prob juris noted (US Jan 9, 2009) (No 08-322).

${ }^{125}$ See, for example, Grutter v Bollinger, 539 US 306 (2003); Georgia v Ashcroft, 539 US 
Roberts Court is the Kennedy Court on similar topics. ${ }^{126}$ Justice Kennedy cast the decisive vote in the Roberts Court's most recent foray into school desegregation, although no one joined his opinion in full. ${ }^{127} \mathrm{He}$ did the same in $L U L A C$, vindicating one of the claims of impermissible race-based vote dilution, while rejecting another, and ignoring a claim of racial gerrymandering. ${ }^{128}$ His opinion there appeared to express genuine discomfort at times with the potential expansiveness of the VRA. ${ }^{129}$ Even when he recrafted VRA doctrine in order to strike down one district as diluting the Hispanic vote, he did so by challenging other aspects of the plan that he considered as violating notions of "cultural compactness." ${ }^{130}$ The plan diluted the Hispanic vote by taking Hispanic voters out of one district where they "naturally" belonged and were on the verge of political opportunity, but it also tried to compensate with the creation of an "unnatural" district that cobbled together far-flung, culturally distinct Hispanic commu-

461 (2003); Easley v Cromartie, 532 US 234 (2001); Shaw v Reno, 509 US 630 (1993); Richmond v 7.A. Croson Co., 488 US 469 (1989); Adarand Constructors, Inc. v Peña, 515 US 200 (1995).

${ }^{126}$ See generally Heather Gerken, Fustice Kennedy and the Domains of Equal Protection, 121 Harv L Rev 104 (2007); Guy-Uriel Charles, Race, Redistricting, and Representation, 68 Ohio St L J 1185 (2007). Professors Gerken and Charles view Justice Kennedy's opinions as evolving toward a more complex view of race than expressed here. They consider his recent opinions as softening on the themes of colorblindness and racial essentialism, whereas I see them as relatively consistent with his prior decisions on racial gerrymandering and affirmative action.

${ }^{127}$ See Parents Involved in Community Schools v Seattle School District No. 1, $127 \mathrm{~S} \mathrm{Ct}$ 2738, 2788 (2007) (Kennedy, J, concurring in part and concurring in the judgment).

${ }^{128}$ LULAC, 548 US at 424-47.

${ }^{129}$ See id at 446 (worrying about an interpretation of the VRA that "unnecessarily infused race into virtually every redistricting, raising serious constitutional questions"); Nathaniel Persily, The Promise and Pitfalls of the New Voting Rights Act, 117 Yale L J 174, 246-47 \& n 254 (2007).

${ }^{130}$ LULAC, 548 US at 428-43; Daniel R. Ortiz, Cultural Compactness, 105 Mich L Rev First Impressions 48 (2006), online at http://www.michiganlawreview.org/firstimpressions/ vol105/oritz.pdf. Because Justice Kennedy voted to strike down a district as violating the Voting Rights Act, one might consider him more receptive than he is to claims of racebased vote dilution. I think it is fair to say that Kennedy was less concerned about the district (District 23) that he struck down than he was about a nearby Hispanic district (District 25) that allegedly compensated for its loss. That district, which he viewed as cobbling together distant and distinct Hispanic communities, was subject to a Shaw claim of racial predominance. Kennedy could not get a majority to strike down that district as excessively race-based, so instead he sided with the four more liberal Justices to craft an opinion that effectively said such a far-flung district was inadequate compensation for the loss of a different district that was culturally compact. He did not rule on the Shaw claim for District 25 because he assumed (correctly) than any remedial plan that addressed the VRA violation in District 23 would require a redrawing of District 25. 
nities. ${ }^{131}$ Although Justice Kennedy ultimately voted to strike down the relevant district because of its race-based dilutive effects, his opinion is reminiscent of his others where he expressed concern about the excessive use of race in drawing districts. ${ }^{132}$

Last term's VRA case, Riley $v$ Kennedy, ${ }^{133}$ arose from such a unique set of facts that it is difficult to assess its long-term significance. The precise issue involved whether Section 5 of the VRA requires a covered state to preclear a former voting law that was only brought into effect once a state court struck down a successor statute under the state constitution. The Court ruled that the state did not need to seek preclearance because the unconstitutional law never technically went into effect. Despite the arcane nature of the case, legal academics quickly took to blogs to argue, sometimes acrimoniously, over the legal importance of the decision. ${ }^{134}$ The case is significant, if at all, as a window on how the Court views the VRA in general, especially given that it will soon weigh in on its constitutionality. It is somewhat rare for an opinion that limits the reach of the VRA to receive seven votes of support, let alone with Justice Ginsburg as the author. That alone might suggest the stakes were low or the issue was sui generis.

${ }^{131}$ See LULAC, 548 US at 429 ("[T]he State [can] use one majority-minority district to compensate for the absence of another only when the racial group in each area had a $\$ 2$ right. . . ."); see also Ortiz, 105 Mich L Rev First Impressions at 49 (cited in note 130) (describing the importance of the Court's move from a geographic to a cultural theory of compactness).

${ }^{132}$ See, for example, Miller $v$ Johnson, 515 US 900, 927 (1995) (subjecting Georgia congressional district to strict scrutiny because it was excessively race-based); Bush $v$ Vera, 517 US 952, 999 (1996) (Kennedy, J, concurring) ("If, however, the bizarre shape of the district is attributable to race-based districting unjustified by a compelling interest (e.g., gratuitous race-based districting or use of race as a proxy for other interests), such districts may 'cause constitutional harm insofar as they convey the message that political identity is, or should be, predominantly racial.'”); see also Georgia v Ashcroft, 539 US 461, 491 (Kennedy, J, concurring) (expressing concern about the necessarily predominant use of race in districts drawn pursuant to the Voting Rights Act).

133128 S Ct 1970 (2008).

${ }^{134}$ See Rick Hills, Civil Rights Lawyers' Ignorance of Local Government Law, Prawfsblawg (May 30, 2008), online at http://prawfsblawg.blogs.com/prawfsblawg/2008/05/civilrights-la.html (arguing that the case represents the trivialization of voting rights litigation); Pamela Karlan, Rick Hill' Marshall McLuban Moment, Balkinization (June 4, 2008), online at http://balkin.blogspot.com/2008/06/rick-hills-marshall-mcluhan-moment.html (providing a pointed critique of Hills's post from the lawyer who argued Riley); Mike Pitts, Pitts on Hills on Riley and the VRA, Election L Blog (June 2, 2008), online at http:// electionlawblog.org/archives/010956.html (refuting Hills's claim that the law at issue benefited minority voters); Rick Pildes, Pildes on Riley Decision, Election L Blog (May 27, 2008), online at http://electionlawblog.org/archives/010904.html (arguing that the majority opinion and dissent suggest greater skepticism of the Section 5 regime). 
Perhaps the case signifies the fatigue of the Court with the VRA disputes on the jurisprudential periphery and reluctance to expand the scope of the VRA by resolving the remaining open questions in a direction more favorable to civil rights. Chief Justice Roberts signaled quite clearly where he was on such peripheral questions, if not the core impact of the VRA, when in LULAC he complained, "It is a sordid business, this divvying us up by race." ${ }^{135} \mathrm{He}$ and others sounded a similar note in the oral argument in the present term's first VRA case, Bartlett v Strickland. ${ }^{136}$ That case asks whether Section 2 of the VRA requires jurisdictions to draw districts that may be under 50 percent minority. For the most part, courts have operated under the assumption that a minority community must be able to constitute over 50 percent of a potential district before it can have a viable claim of vote dilution under Section 2 of the VRA. ${ }^{137}$ The Court has repeatedly avoided the question until this year ${ }^{138}$ and, as with Riley, appears poised to block further attempts to venture into uncharted territory concerning race and redistricting. This reticence comes from a general uneasiness concerning both race-consciousness and standardless discretion for rules governing redistricting.

The larger question for the current term is whether this reticence has reached a point that the Court is willing to take the dramatic step of declaring Section 5 of the VRA unconstitutional. The case now on appeal to the Supreme Court asks whether the Section 5 regime, reauthorized in 2006, has become anachronistic to the point of being unconstitutional. ${ }^{139}$ Section 5 requires certain

${ }^{135}$ LULAC, 548 US at 511 (Roberts, CJ, dissenting).

${ }^{136} 2009$ WL 578634, transcript online at http://www.supremecourtus.gov/oral_arguments/argument_transcripts/07-689.pdf (comments of Chief Justice Roberts, Justice Kennedy, and Justice Alito expressing concern about an interpretation of the VRA that would lead it to apply to a greater number of districts).

${ }^{137}$ See Pender County v Bartlett, 649 SE2d 364, 372 (NC 2007), cert granted Bartlett v Strickland, No 07-689 (oral arguments heard Oct 14, 2008) ("Although the United States Supreme Court has left open this issue, the majority of federal circuit courts confronting the question have concluded that, when a district must be created pursuant to Section 2, it must be a majority-minority district.").

${ }^{138}$ See $L U L A C, 548$ US at 445 (opinion of Kennedy) (rejecting claim that white Democrat constituted African American candidate of choice, in part because of constitutional questions that would be raised). In several other cases the Court has assumed without deciding that districts under 50 percent minority might be protected under Section 2. Fohnson v De Grandy, 512 US at 1009; Voinovich v Quilter, 507 US 146, 154 (1993); Thornburgh v Gingles, 478 US 30, 46-47 n 12 (1986).

${ }^{139}$ Northwest Austin Municipal Utility District Number One v Mukasey, 557 F Supp 2d 9 (DDC 2008), prob juris noted (US Jan 9, 2009) (No 08-322) (“NAMUDNO”). 
covered jurisdictions to submit their voting laws for preclearance by the Attorney General or the U.S. District Court for the District of Columbia, which decide whether such laws have the purpose or effect of "retrogressing" with respect to minority voting rights. ${ }^{140}$ Although it was subsequently amended, the "coverage formula," originally established in 1965, included jurisdictions that had low voter turnout in the 1964 election and employed voting "tests or devices," such as a literacy test. ${ }^{141}$ Very few jurisdictions have "bailed out" of coverage, as permitted by the statute, ${ }^{142}$ by demonstrating a consistent pattern of voting rights compliance and other factors over a ten-year period. In the current appeal, a municipal utility district in Austin argues that it should not be forced to preclear its voting laws, given its lack of a history of discrimination, simply because the state of Texas is a covered jurisdiction. ${ }^{143}$

It is possible that the concern several members of the Court have expressed regarding race and redistricting, let alone excesses of federal power, will lead them to strike down the VRA. Moreover, the election of Barack Obama may add to their convictions that such a regime is unnecessary and out of date. Section 5 was born out of the frustration of civil rights advocates for whom case-bycase federal court adjudication was an ineffective means of controlling mainly Southern obstructionist jurisdictions. Those jurisdictions would find creative ways to comply with court orders while ensuring the disenfranchisement of African Americans. Even if they were not inclined to do so previously, some Justices may view record African American turnout in the 2008 election, let alone Barack Obama's success in a few covered jurisdictions, ${ }^{144}$ as

\footnotetext{
${ }^{140}$ Voting Rights Act (VRA), $§ 5,42$ USC $\$ 1973 c$ (2000).

${ }^{141}$ See 89 PL 110; 79 Stat 437.

${ }^{142}$ See 42 USC $\$ 1973 \mathrm{~b}(\mathrm{a})(1)$ (2000). On the history of bailout, see Michael P. McDonald, Who's Covered? Coverage Formula and Bailout, in David L. Epstein et al, eds, The Future of the Voting Rights Act 255, 257 (2006).

${ }^{143}$ NAMUDNO, 557 F Supp 2d 9, 24 (DDC 2008), prob juris noted (US Jan 9, 2009) (No 08-322)

${ }^{144}$ Almost all of Virginia and one-third of North Carolina (two states Obama won) are covered, as are a few localities in New York, California, Florida, New Hampshire, and Michigan. However, Alabama, Alaska, Arizona, Georgia, Louisiana, Mississippi, South Carolina, and Texas (all states Obama lost) are covered in their entirety. See Section 5 Covered Jurisdictions, http://www.usdoj.gov/crt/voting/sec_5/covered.php. It is worth noting that Obama lost all states that are completely covered by Section 5. In an amicus brief filed in the NAMUDNO case, Stephen Ansolabehere, Charles Stewart, and I point out that the 2008 election, far from counting against the constitutionality of Section 5,
} 
evidence that the fundamental justification for Section 5 has been removed. ${ }^{145}$

The restraint and minimalism that animates the Court's move toward greater emphasis on as-applied challenges may also come to lead the Court to uphold the VRA against this most recent challenge. Striking down the VRA on federalism grounds, as the plaintiffs request, would constitute the most significant court challenge to Congressional power since the Lochner era. ${ }^{146}$ More modest courses of action could satisfy the majority's discomfort with the Section 5 regime (assuming it has any) while still upholding the law on its face. In particular, the Court could reject the present challenge to the coverage regime, but allow for later challenges to the criteria for bailout. In other words, as in McConnell/WRTL, Washington Grange, and Crawford, it could uphold the law while recognizing that in a future individual case the Constitution might require that the bar should be lowered for a covered jurisdiction to bail out. ${ }^{147}$ It could say that the state of Texas (or other covered

actually helps distinguish the covered and uncovered jurisdictions. Using both exit poll and actual election results at the county level, we argue that the gap in the voting preferences of whites and minorities remains much wider in the covered jurisdictions. See Brief Amicus Curiae of Nathaniel Persily, Stephen Ansolabehere, and Charles Stewart in Support of Neither Party, Northwest Austin Municipal Utility District v Holder (No 08-322), prob juris noted (US Jan 9, 2009).

${ }^{145}$ Compare Abigail and Stephan Thernstrom, Racial Gerrymandering Is Unnecessary, Wall St J (November 11, 2008), available at http://online.wsj.com/article/SB1226373739375 16543.html (suggesting that an Obama victory means that "the doors of electoral opportunity in America are open to all" and arguing that "the Voting Rights Act should therefore be reconsidered") to Kristen Clarke, The Impact of the 2008 Presidential Election on Efforts to Measure Racially Polarized Voting in Future Voting Rights Act Litigation, Harvard L \& Policy Rev (forthcoming 2009) (arguing that the Obama victory should not fundamentally alter the concerns that undergird the VRA).

${ }^{146}$ See Persily, 117 Yale L J at 251-53 (cited in note 129).

${ }^{147}$ The plaintiffs cleverly anticipated this by phrasing their claim, alternatively and ambiguously, as an as-applied challenge. See NAMUDNO, $557 \mathrm{~F}$ Supp $2 \mathrm{~d}$ at 76 . It is possible that the Court might take their invitation and declare the law unconstitutional as-applied to such a small jurisdiction or strike down parts of the statute that prevent such a jurisdiction from independently bailing out. Doing so would allow the Court to escape the headlines of striking down the VRA, while chipping away at the coverage regime. There are several problems with this approach that would not be applicable to a later attempt to challenge a refusal of bailout as unconstitutional. First, it is unclear as a threshold matter whether one can launch as-applied challenges to exercises of Congressional power on federalism grounds. See Gillian E. Metzger, Facial Challenges and Federalism, 105 Colum L Rev 873 (2005). Second, the Court has already upheld the coverage of subjurisdictions as constitutional and the statute does not contemplate the possibility of every subjurisdiction independently seeking a declaratory judgment in the U.S. District Court for D.C. to escape coverage. See City of Rome v United States, 446 US 156 (1980). Instead, the Court may simply say that the remedy for the utility district here is for the state of Texas to attempt to bail out, and if it is denied, the Court can then review and recraft the criteria for bailout. 
jurisdictions) should attempt to bail out of coverage first and the criteria used to reject its bailout request should be interpreted in such a way to avoid constitutional difficulty. The bailout regime, itself, operates as an analog to as-applied challenges: allowing those jurisdictions that consider themselves unfairly captured to prove the law should not be applicable to them. Given that the Roberts Court has at least hinted at the continuing constitutionality of the VRA, ${ }^{148}$ a majority uncomfortable with the new VRA might prefer a strategy of upholding on its face today while allowing for quasi-as-applied challenges later through lowering the hurdles for bailout.

\section{REGULATION OF POLITICAL PARTIES}

The Rehnquist Court's decisions concerning the rights of political parties tended to follow two themes. The first was a general disregard for minor parties' claims either for ballot access or other associational rights. ${ }^{149}$ The second was robust protection for major parties' rights, as illustrated in decisions striking down laws that infringed on a major party's right to include independents ${ }^{150}$ or exclude nonmembers ${ }^{151}$ from voting in its primary. For the most part, these cases had a greater impact on academic discussion than on party behavior or policy debate. The cases posed rich theoretical questions about the uniqueness of political parties as quasistate actors that are at once protected by the First Amendment but also have the capacity to craft election laws to infringe on voters' and other parties' rights. ${ }^{152}$

\footnotetext{
${ }^{148}$ Even the more conservative members of the Court have suggested that the previous incarnation of the VRA was constitutional. See LULAC, 548 US at 517 (Scalia, J, dissenting in part) (joined by Roberts, Alito, and Thomas); Nathaniel Persily, Strict in Theory, Loopy in Fact, 105 Mich L Rev First Impressions 43 (2006) (highlighting the unprecedented move by Scalia to vote to uphold a racially gerrymandered district on the basis of the compelling state interest of complying with Section 5 of the Voting Rights Act).

${ }^{149}$ See, for example, Timmons v Twin Cities Area New Party, 520 US 351 (1997) (rejecting claim by minor party for fusion candidacy); Munro v Socialist Workers Party, 479 US 189 (1986) (upholding ballot access requirement); Clingman v Beaver, 544 US 581 (2005) (rejecting Libertarian party's right to allow members affiliated with other parties to vote in its primary); Arkansas Ed. Television Comm'n v Forbes, 523 US 666 (1997) (rejecting claim of independent candidate to be part of candidate debate on public television). But see Norman v Reed, 502 US 279 (1992) (vindicating rights of minor party in Illinois).

${ }^{150}$ See Tashjian v Republican Party of Conn., 479 US 208 (1986).

${ }^{151}$ See California Democratic Party v Fones, 530 US 567 (2000); see also Eu v San Francisco County Democratic Central Comm., 489 US 214 (1989).

${ }^{152}$ See Nathaniel Persily, Toward a Functional Defense of Political Party Autonomy, 76 NYU
} 
The Roberts Court appears to be hewing close to the Rehnquist Court's line in the two party-related cases it decided in the 2007-2008 term, as well as its discussion of party rights in both Randall $v$ Sorrell and LULAC. Although too much should not be made from these few cases (especially given the lopsided votes in last term's cases), the placement of most members of the current Court on the relevant themes has now become apparent. In general, the Justices can be arrayed roughly according to their concern for major parties' associational rights claims and for the rights of outsiders (minor parties or insurgent candidates) who seek to challenge the two major parties.

Justices Stevens and Ginsburg are least willing to protect major parties in their claims of associational rights or to grant credence to state interests that mask bias against minor parties. Thus, they (along with Justice Souter) dissented when the Court upheld the antifusion law widely believed to inhibit the growth of minor parties, ${ }^{153}$ when it rejected the Libertarian Party's claim to include other parties' members in its primary, ${ }^{154}$ and when it upheld the Texas Republican gerrymander. ${ }^{155}$ Justice Souter appears to differ with Stevens and Ginsburg in the value he places on the twoparty system ${ }^{156}$ and in the autonomy rights of all political parties. Stevens and Ginsburg, but not Justice Souter, were therefore willing to uphold the blanket primary in California against claims it invaded parties' associational rights by forcing parties to accept outsiders in their primaries. ${ }^{157}$ All three, of course, voted to uphold both the nonpartisan blanket primary in Washington Grange and the judicial nomination method in Lopez Torres, although Justice Stevens, joined by Souter, went out of his way to criticize the wisdom of the latter. ${ }^{158}$

Justice Breyer differs from the other more liberal members of

L Rev 750 (2001); Nathaniel Persily and Bruce E. Cain, The Legal Status of Political Parties: A Reassessment of Competing Paradigms, 100 Colum L Rev 775 (2000); Bruce E. Cain, Point/ Counterpoint: Party Autonomy and Two-Party Electoral Competition, 149 U Pa L Rev 793 (2001); Samuel Issacharoff, Private Parties with Public Purpose: Political Parties, Associational Freedoms, and Partisan Competition, 101 Colum L Rev 274 (2001).

${ }^{153}$ See Timmons, 520 US 351, 370 (Stevens, J, dissenting).

${ }^{154}$ Clingman, 544 US 581, 608 (Stevens, J, dissenting).

${ }^{155}$ LULAC, 548 US at 447 (Stevens, J, dissenting); id at 483 (Souter, J, dissenting).

${ }^{156}$ See Timmons, 520 US 351, 382 (Souter, J, dissenting).

${ }^{157}$ fones, 530 US at 590 (Stevens, J, dissenting).

${ }^{158}$ See New York v Lopez Torres, 128 S Ct 791, 801 (2008) (Stevens, J, concurring). 
the Court in his focus on entrenchment above other concerns. His controlling opinion for the Court in Randall (joined only by Chief Justice Roberts and Justice Alito) best exemplifies his thinking. Focusing on the law's effect on challengers attempting to compete against incumbents, he found the restrictions on political party contributions to be an especially disconcerting "danger sign" for the contribution limits at issue. ${ }^{159}$ Similarly, his approach to partisan gerrymandering in Vieth and LULAC focused on whether one party attempts to use its power in the redistricting process to keep itself in power. ${ }^{160} \mathrm{He}$ also joined separate concurrences in both Clingman v Beaver ${ }^{161}$ and Lopez Torres ${ }^{162}$ in order to emphasize an alternative, narrower holding that might allow a minor party or insurgent candidate to have a successful claim were the election law at issue more hostile to competition. ${ }^{163}$ However, Breyer also seems more concerned about protecting the rights of major parties than those of minor parties, as exemplified in his willingness to join the Court in both striking down California's blanket primary and upholding Minnesota's ban on fusion candidacies. ${ }^{164}$

Justice Kennedy often shares Breyer's concerns about entrenchment, ${ }^{165}$ although in other cases he supplements those concerns with an unsurpassed First Amendment libertarianism to protect party speech and associational rights. His separate concurrence in California Democratic Party $v$ fones, ${ }^{166}$ for example, stands out as a

${ }^{159}$ See Randall v Sorrell, 548 US 230 (2006) (opinion of Breyer)

${ }^{160}$ LULAC, 548 US at 491-92 (Breyer, J, concurring in part and dissenting in part); Vieth $v$ fubelirer, 541 US 267, 355-68 (2004) (Breyer, J, dissenting).

${ }^{161}$ See Clingman, 544 US at 603 (O'Connor, J, concurring) (“[T]he State itself is controlled by the political party or parties in power, which presumably have an incentive to shape the rules of the electoral game to their own benefit.").

${ }^{162}$ Lopez Torres, $128 \mathrm{~S}$ Ct at 801 (Kennedy, J, concurring).

${ }^{163}$ The two cases that do not fit this mold are Timmons, in which Breyer joins the majority to uphold the antifusion ban, and fones, where Breyer joins the majority to strike down California's blanket primary.

${ }^{164}$ See fones, 530 US 567; Timmons, 520 US 351.

${ }^{165}$ Kennedy expressed these concerns in a case before Breyer even joined the Court when he dissented from a decision that upheld Hawaii's ban on write-in voting. See Burdick $v$ Takushi, 504 US 428, 442 (Kennedy, J, dissenting) (arguing that the ban on write-in votes alongside restrictive ballot access laws diminished the right to cast a meaningful vote).

${ }^{166}$ California Democratic Party v fones, 530 US 567, 586, 590 (2000) (Kennedy, J, concurring) ("When the State seeks to regulate a political party's nomination process as a means to shape and control political doctrine and the scope of political choice, the First Amendment gives substantial protection to the party from the manipulation. In a free society the State is directed by political doctrine, not the other way around."). 
broad condemnation of state attempts to limit party autonomy in both the nomination process and campaign finance. Moreover, his concurrence in Vieth urges future challenges to partisan gerrymanders to focus on the potential costs to freedom of association from one party's discrimination against another party's voters. ${ }^{167}$ Because he appears to place greater importance on parties' right to speak and associate, he and Breyer also disagree in the party finance cases ${ }^{168}$ and in Washington Grange, where Kennedy joined Scalia's dissent arguing against the constitutionality of the nonpartisan blanket primary.

Justices Thomas and Scalia, in contrast, tend to side against minor parties, while protecting political parties' rights to exclude nonmembers. The one case that has divided them (as it divided Breyer and Kennedy) was Washington Grange, for which Justice Thomas wrote the opinion for the Court and Justice Scalia (joined by Justice Kennedy) vigorously dissented. ${ }^{169}$ In that case they simply appeared to disagree as to the likelihood that the nonpartisan blanket primary would blur the difference between a party preference and a party endorsement.

Chief Justice Roberts and Justice Alito have been joined at the hip when it comes to the party cases. In an opinion only for themselves in $L U L A C$, they rejected the partisan gerrymandering claim without saying such claims would never be justiciable. ${ }^{170} \mathrm{In}$ Randall, they (and they alone) joined Breyer in the opinion that also emphasized the problems with low limits on party contributions. ${ }^{171}$ While joining the majority in Lopez Torres, they joined

${ }^{167}$ Vieth, 541 US at 316 (Kennedy, J, concurring).

${ }^{168}$ See Colo. Republican Fed. Campaign Comm. v Fec, 518 US 604 (1996) ("Colorado Republican I"); Colo. Republican Fed. Campaign Comm. v FEC, 533 US 431 (2001) ("Colorado Republican II").

${ }^{169}$ Wash. State Grange v Wash. State Republican Party, 128 S Ct 1184 (2008).

${ }^{170}$ LULAC, 548 US at 492 (Roberts, J, concurring in the judgment in part, concurring in part, dissenting in part) ("The question whether any such standard [for partisan gerrymandering] exists - that is, whether a challenge to a political gerrymander presents a justiciable case or controversy-has not been argued in these cases."). Roberts's curt treatment of the partisan gerrymandering claim in $L U L A C$ is bizarre, given that the Court had earlier remanded the case in light of Vieth. Vieth was only about partisan gerrymandering. The district court's post-Vieth opinion, which led to the appeal the Supreme Court considered in $L U L A C$, was almost exclusively about whether the Texas gerrymander failed any possible standard that could have satisfied Justice Kennedy's opinion in Vieth. The justiciability of partisan gerrymandering claims and the presentation of alternative standards were certainly argued in the case.

${ }^{171}$ Randall, 548 US at 236. 
together (alone again) in Roberts's separate concurrence in Washington Grange to emphasize that a showing of the likelihood of confusion would be enough to strike down the nonpartisan blanket primary.

Washington Grange is therefore the tea leaf that deserves reading to surmise what might lie ahead for the Roberts Court in party autonomy cases. Not only because it was a unanimous decision, but also because it falls in line with the Rehnquist Court cases on marginalizing those that challenge the two major parties, Lopez Torres was not a surprise. ${ }^{172}$ The fact that Justice Scalia could only get Justice Kennedy to join him in dissent in Washington Grange may suggest some sort of shift away from the thick autonomy arguments that he wrote for a seven-member majority in California Democratic Party $v$ fones. However, the limited resolution of the facial challenge, as well as the more extreme autonomy argument the parties made in Washington Grange, should caution against viewing the case as a sea change. Now that the Court has established the basic contours of a party's right to exclude or include certain classes of voters in its primary, perhaps a case like Washington Grange is simply viewed as implicating a peripheral autonomy right concerning the control over the party's brand name. In some respects, the party cases from this past Term may simply be emblematic of the general restraint the Roberts Court has exercised over election laws outside the context of campaign finance. Perhaps Chief Justice Roberts, in particular, viewed Washington Grange in the light of Crawford that would soon be decided. That case laid the groundwork for the facial holding of Crawford, and by upholding both laws the Court could avoid the charge that it was defending the rights of powerful political parties while minimizing the importance of the voting rights of those without photo ID.

\section{BARRIERS TO PARTICIPATION}

The Crawford case was not the Roberts Court's first and only entry into the fray over voter integrity and access. Both before

\footnotetext{
${ }^{172}$ If one views the case more as one about judicial elections, it is even less surprising. The Court has hinted at its discomfort with judicial elections while protecting judicial campaign speech. See Republican Party of Minnesota v White, 536 US 765 (2002). The antidemocratic form judicial elections take in New York might be less troublesome to one who believes electing judges is a mistake from the outset.
} 
and after Crawford, the Court waded into the debate. In Purcell $v$ Gonzalez, ${ }^{173}$ a case upholding at a preliminary stage Arizona's ID requirement, the Court forecasted the concerns about perceptions of fraud that Justice Stevens eventually expressed in Crawford. Purcell emphasized, in particular, that "Voter fraud drives honest citizens out of the democratic process and breeds distrust of our government. Voters who fear their legitimate votes will be outweighed by fraudulent ones will feel disenfranchised." ${ }^{174}$ And in a surprising (also interlocutory) opinion less than a month before the 2008 election, a unanimous Court weighed in to establish that the Help America Vote Act does not confer a private right of action to the Republican Party in its attempt to force the Ohio Secretary of State to provide mismatch lists from the voter registration file. ${ }^{175}$ The lasting impact of these cases, particularly Crawford, will likely be felt in the asymmetric evidentiary burdens they have required for proving actual or perceived fraud, on the one hand, and measurable disenfranchisement on the other.

The Court's holding in Crawford that the state interest in preventing actual or perceived fraud justified the ID law is as important a development as its assessment of the burden on voters described earlier. The Crawford Court found the lack of evidence of past instances of voter impersonation fraud in Indiana-the kind an ID law would prevent - to be unimportant in justifying the law. Such fraud had occurred at some point in other parts of the country, ${ }^{176}$ Justice Stevens's opinion maintained, and Indiana and other states had experienced other types of fraud, such as absentee voter fraud. Drawing from the campaign finance case law recognizing

\footnotetext{
${ }^{173}$ Purcell v Gonzalez, 127 S Ct 5 (2006).

${ }^{174} \mathrm{Id}$ at 7.

${ }^{175}$ Brunner v Obio Republican Party, 129 S Ct 5 (2008).

${ }^{176}$ The only two instances of in-person fraud the controlling opinion identifies are one case in Washington and one anecdote from the days of Tammany Hall. See Crawford, 128 $\mathrm{S}$ Ct at $1619 \mathrm{nn}$ 11-12. The Circuit Court opinion suggested that such lack of evidence is likely the result of nonenforcement of minor criminal laws, akin to littering, as well as the inherent difficulties of detecting such fraud. Crawford, 472 F3d 949, 953-54. Heated debate may continue over these empirics of voter fraud, but few argue that no ineligible voters end up casting votes in elections. At the same time, concerted efforts by groups to commit fraud by voter impersonation almost never happen. The benefits of such a strategy are too low or too difficult to quantify given that the conspirator must coordinate a number of voters sufficient to overcome the expected margin of loss. And the costs are too high (both in terms of moving from one polling place to the next and potentially getting caught) to make this a smart strategy to rig an election. This is especially true given that other means of fraud, such as through absentee ballots or tampering with vote totals, might require less effort, better avoid detection, and work more effectively.
} 
the state interest in combating perceptions of corruption, ${ }^{177}$ the controlling opinion found the ID law further justified as safeguarding voter confidence in the integrity of elections. ${ }^{178}$ Even if no actual fraud had occurred or would be prevented, the argument went, a voter ID law might reasonably address voters' fears of electoral mischief. ${ }^{179}$

In a study published in the Harvard Law Review the same week as the Crawford decision, Stephen Ansolabehere and I presented recent data as to public perceptions of vote fraud. ${ }^{180}$ We found that a large share of the public believes voter impersonation occurs very often $(9$ percent) or somewhat often ( 32 percent). The same pattern holds for questions about double voting or noncitizen voting. However, we find that, contrary to the contention in Purcell, respondents who perceive a great deal of fraud are no less likely to turn out to vote. Nor does there seem to be any difference in perceptions of fraud based on whether the respondent lives in a state with a stricter ID requirement or was personally asked for ID.

Although the available empirical evidence might undermine the strong claims about confidence and voter ID laws, such an argument (as in campaign finance cases) may simply represent "piling on" once the Court has lowered the standard so low for proof of actual fraud. Whether a court relies on opportunities for voter fraud, isolated and perhaps distant instances of actual fraud, or presumed voter perception of fraud, the outcome will still be the same. The central question is whether the state can act prophylactically to avoid an unlikely, even if widely assumed, threat to democracy. The Court has answered "yes" to that question, at least when the number of people who may not then vote as a consequence is difficult to define or identify.

\footnotetext{
${ }^{177}$ See Nathaniel Persily and Kelli Lammie, Perceptions of Corruption and Campaign Finance: When Public Opinion Determines Constitutional Law, 153 U Pa L Rev 119, 122-23 (2004).

${ }^{178}$ Crawford, $128 \mathrm{~S} \mathrm{Ct}$ at 1620 ("[P]ublic confidence in the integrity of the electoral process has independent significance, because it encourages citizen participation in the democratic process.”).

${ }^{179}$ Indeed, one also must have some sympathy for Justice Stevens's evaluation of the threat of voter fraud: as a Republican growing up in Chicago, election fraud was not a theoretical problem for him; it was a way of life.

${ }^{180}$ See Stephen Ansolabehere and Nathaniel Persily, Vote Fraud in the Eye of the Beholder: The Role of Public Opinion in the Challenge to Voter Identification Requirements, 121 Harv L Rev 1737 (2008).
} 
The question then turns to whether the constitutional balance that Crawford has struck would tip against such laws if more concrete or substantial evidence of vote hindrance or denial could be demonstrated. Here again, though, the question as to what Crawford means with respect to future as-applied challenges becomes critical. One view of Crawford dictates that the primary job of courts will be to carve out exceptions for individuals and groups disadvantaged by voting laws. If that represents an accurate reading, then it is difficult to see how most laws of this ilk would not then be justified (or at least as justified as the Indiana law) by an appeal to the same antifraud justifications. ${ }^{181}$

The controversy over voter fraud has only intensified and become more politicized since the Crawford decision. It manifested itself during the 2008 campaign in the blowup over ACORN's error-prone voter registration drives ${ }^{182}$ as well as efforts in various states to create registration mismatch lists that threatened to lead to challenges to voter qualifications in the polling place. Those threats rarely materialized, but the lawsuits provided a template for what may lie ahead. Crawford will continue to serve as the reigning precedent for the next generation of ID laws, such as those requiring proof of citizenship for voting. ${ }^{183}$ However, the more prevalent cases pitting claims of fraud against claims of access concern laws that regulate registration drives ${ }^{184}$ or that erect hurdles for voters whose registration status is questioned due to discrepancies between the voter registration database and some other database.

The Supreme Court issued an unexpected decision relevant to the last type of case when it held that a political party could not sue the Ohio Secretary of State under the Help America Vote Act

${ }^{181}$ In applying Crawford so as to uphold a similar photo ID law in Georgia, an Eleventh Circuit panel did not even seem to leave open the possibility of as-applied challenges. See Common Cause/Georgia v Billups, 554 F3d 1340 (11th Cir 2009).

${ }^{182}$ See Rotten Acorn, Recent Fraud, online at http://www.rottenacorn.com/activity Map.html.

${ }^{183}$ See Ian Urbina, Voter ID Battle Shifts to Proof of Citizenship, New York Times (May 12, 2008), online at http://www.nytimes.com/2008/05/12/us/politics/12vote.html?_r =1 \&hp\&oref = login (describing proposed, but as yet unpassed, constitutional amendment in Missouri that would require proof of citizenship from voters and noting similar bills in nineteen others states).

${ }^{184}$ See League of Women Voters of Florida v Browning, 575 F Supp 2d 1298 (SD Fla 2008) (citing Crawford's analysis of both fraud and as-applied challenges and upholding regulations of third-party registration drives). 
to force her to release a list of mismatches between the state's voter registration database and the motor vehicles and Social Security databases. ${ }^{185}$ As a consequence of that holding, great variation will continue to exist between states as to how they handle discrepancies between the HAVA-required statewide voter registration database ${ }^{186}$ and other lists, such as the Social Security and department of motor vehicles databases. The cause for concern arises from the large number of errors (sometimes affecting 20 percent of new registrations) that occur because of transcription problems, changed names, or faulty address information in the databases. ${ }^{187}$ States that purge mismatched voters from the voter rolls or require them to cure the discrepancy through various steps do so for fraud-prevention or election-integrity reasons similar to those expressed in Crawford. At least one court that has considered such a "no-match, no-vote law" concluded that the law was facially constitutional and justified by the state's interest in combating fraud or its appearance. ${ }^{188}$ Moreover, like Crawford, as-applied challenges were viewed as a sufficient safeguard for mismatched voters who found it particularly difficult to cure the registration defect.

\section{Conclusion}

Despite changed membership on the Court and the passage of eights years, Bush v Gore continues to cast a shadow over the election cases the Supreme Court considers, as well as the elections

\footnotetext{
${ }^{185}$ Brunner v Obio Republican Party, 129 S Ct 5 (2008).

${ }^{186}$ See Title 42 USC $\$ 15483$ (2000 ed, Supp V) (describing requirement of statewide voter registration database).

${ }^{187}$ See Justin Levitt, Wendy R. Weiser, and Ana Munoz, Making the List: Database Matching and Verification Processes for Voter Registration ii (Brennan Center, 2006).

${ }^{188}$ See Florida State Conference of the NAACP v Browning, 569 F Supp 2d 1237 (N D Fla 2008) (upholding Florida's "no-match, no-vote" law). The law required that individuals whose voter registration forms could not be verified against DMV or Social Security databases needed to resolve the discrepancy. They could do so by presenting in person or mailing a copy of their ID to their local board of elections. If they failed to do so before the election, they would be required to cast a provisional ballot, which they could cure by producing an ID to the board shortly afterward. As with Crawford, the state justified the law as an antifraud measure that would build public confidence, despite little historical evidence in Florida of fraud occurring, outside the context of absentee ballots. $569 \mathrm{~F}$ Supp $2 \mathrm{~d}$ at 1261 . The plaintiffs, as in Crawford, could not produce before the election anyone who would not be able to vote as a result. The Court took refuge in Crawford's holding concerning facial and as-applied challenges to suggest that burdened voters could seek a remedy as applied to themselves.
} 
themselves. When parties view the stakes of every legal dispute as if a presidential election might ride on it, no constitutional question regarding the operation of elections or campaigns seems too small for judicial resolution. At the same time, each election case often brings with it risks of accusations of politicization of the judiciary, in general, or partisanship of judges, in particular. Breaking with this legacy requires that the Roberts Court continuously confront a challenge in its election cases to attempt consensus and to proceed incrementally.

The cases from the 2007-2008 term represent concerted effort expended particularly by Chief Justice Roberts to establish an approach to election law that achieves these goals. The controlling opinions of the Court-all joined, but none written, by Robertsexude restraint and minimalism, while ensuring that courts will remain actively and intimately involved in the minutiae of election law. The frequently expressed preference for as-applied challenges led supermajorities of the Court to uphold election laws today that the Court implies might be unconstitutional tomorrow. Indeed, the redefinition or fudging of the differences between facial and as-applied challenges has allowed the Court to disguise what otherwise seem like more transformative election law holdings. The type of as-applied challenge to ID laws Crawford leaves open, for example, might allow for narrow exceptions for especially burdened groups, or a broad invalidation of the law once we learn more about its effects, as with the style of the ballot in Washington Grange. Similarly, when as-applied challenges lead to the crafting of legislative-like rules, as in WRTL, then the Court can have its cake of preserving precedent while substantially eating it too.

Such an approach also represents a subclass of strategies to avoid open conflict with the political branches. Another is the Court's avoidance of arguments that hint, in effect, at politicians behaving too politically. Even when glaringly obvious from the legislative history, the Court shies away from accusations of partisan bias or incumbent entrenchment. In Davis, for example, traditional First Amendment analysis proved ill-suited to striking down the Millionaire's Amendment, when the chief concern arising from the law may have been its underlying incumbent-protection motive. Moreover, whereas the lopsided partisan support for ID laws may persuade lower court judges of their unconstitutionality, even the dissenters in Crawford could not bring themselves to make the 
charge that the law represented an attempt by one party to place obstacles in the way of its opponents' supporters.

Although the low salience of most of the cases from the 2007-2008 term may also explain the surprising degree of consensus, seemingly minor cases engendered heated disagreement for earlier Courts. Furthermore, these cases may prove to be the building blocks for more transformational election law shifts recognizable only in retrospect. With Davis, for example, the Court continues its trend of chipping away at prevailing campaign finance doctrine. Washington Grange and Lopez Torres may prove more significant over the long term if they represent a move away from greater scrutiny both of laws that curtail party autonomy and ones that cement party organizational hegemony. Crawford, too, represents a mere introduction to the voter fraud and suppression debate. This past election suggests the ruling in that case, where the stakes have proven to be low, may project broader, more important signals as to the role of courts in defining the limits of partisan attempts to erect barriers to registration and voting. Finally, Riley's unique facts and lopsided resolution ought not to distract from the possibility that the case may be emblematic of a shifting tide against aggressive enforcement of the Voting Rights Act. For all of these cases from the 2007-2008 term, their implications may become evident even sooner than the opinion authors thought. With four or more election law cases accepted for the subsequent term, the Roberts Court has refused to let these controversies cool or fester before it attempts at some partial resolution. 